\title{
Article \\ Evaluating the Effect of New Gas Solubility and Bubble Point Pressure Models on PVT Parameters and Optimizing Injected Gas Rate in Gas-Lift Dual Gradient Drilling
}

\author{
Naser Golsanami ${ }^{1,2}\left(\mathbb{D}\right.$, Bin Gong ${ }^{2, *}\left(\mathbb{C}\right.$ and Sajjad Negahban ${ }^{3, *}$ \\ 1 State Key Laboratory of Mining Disaster Prevention and Control, Shandong University of Science and \\ Technology, Qingdao 266590, China; golsanami_naser@yahoo.com \\ 2 College of Energy and Mining Engineering, Shandong University of Science and Technology, \\ Qingdao 266590, China \\ 3 Faculty of Mining, Petroleum and Geophysics Engineering, Shahrood University of Technology, \\ Shahrood 3619995161, Iran \\ * Correspondence: skd996579@sdust.edu.cn (B.G.); s.negahban@shahroodut.ac.ir (S.N.); \\ Tel.: +86-13176397921 (B.G.); +98-9125848058 (S.N.)
}

check for

updates

Citation: Golsanami, N.; Gong, B.;

Negahban, S. Evaluating the Effect of New Gas Solubility and Bubble Point Pressure Models on PVT Parameters and Optimizing Injected Gas Rate in Gas-Lift Dual Gradient Drilling. Energies 2022, 15, 1212. https:// doi.org/10.3390/en15031212

Academic Editors: Benoît Daireaux and Yuichi Sugai

Received: 19 November 2021

Accepted: 31 January 2022

Published: 7 February 2022

Publisher's Note: MDPI stays neutral with regard to jurisdictional claims in published maps and institutional affiliations.

Copyright: (C) 2022 by the authors. Licensee MDPI, Basel, Switzerland. This article is an open access article distributed under the terms and conditions of the Creative Commons Attribution (CC BY) license (https:// creativecommons.org/licenses/by/ $4.0 /)$.

\begin{abstract}
Gas-lift dual gradient drilling (DGD) is a solution for the complex problems caused by narrow drilling windows in deepwater drilling. Investigations are lacking on using oil-based drilling fluid in DGD, which is the principal novel idea of the present study. This research compares the results obtained from two new models with those of Standing's correlations for solubility and bubble point pressure. Nitrogen was selected as the injection gas, then the PVT behavior of drilling fluid (oil/water/Nitrogen) in gas-lift DGD was evaluated and compared by coding in MATLAB. Then, these results were used to calculate the bottom hole pressure and finally investigate the optimization of injected gas flow rate. According to the achieved results, the Standing model has some errors in evaluating the PVT behavior of "Nitrogen and oil-based drilling fluids" and is not recommended for the mixtures in the gas-lift DGD. Regarding optimizing gas flow rate, a discrepancy was observed between pressure values obtained from the new models and the Standing model for the case of high liquid flow rates at low gas flow rates because of the difference in PVT parameters. The developed codes are deposited on an online data repository for future users. This study lays the foundation for better planning of drilling in deepwater drilling projects.
\end{abstract}

Keywords: deepwater drilling; gas-lift dual gradient drilling; PVT behavior; standing correlations

\section{Introduction}

As the demand for oil and gas continues to rise, exploration and drilling operations in deep water are being developed by many companies. In the development of these areas, the depleted reservoirs have led the drilling industry to encounter new technical challenges due to the harsh conditions at great depths. Application of conventional drilling in these situations leads to an increase in NPT (non-production time), the number of casings, and consequently, the drilling cost. On the other hand, increasing the casing number has improper impacts on logging, cementing, and perforation operations, and above all, it could reduce the production rate. Nevertheless, there are some solutions to these kinds of challenges. The gas lift dual gradient drilling, as a part of managed pressure drilling (MPD) technology, is one method to overcome the problems met in deep water and also in the reservoirs with narrow drilling windows, where the pore pressure and fracture pressure [1,2] are close. The International Association of Drilling Contractors (IADC) defined dual gradient as "Two or more pressure gradients within selected well sections to manage the well pressure profile".

The concept of gas-lift DGD is very similar to the underbalanced drilling (UBD) technology where Nitrogen or air is injected into the oil-based mud (OBM) to control 
bottom hole pressure (BHP). For several years, great effort has been devoted to the study of utilizing a mixture of gas and drilling fluid (mud). Wallace and Walker [3] and Rizo and Cuenca [4] discussed aerated mud in the drilling industry. Guo et al. [5] studied the optimal air injection rate and the carrying capacity in the aerated drilling fluid. They stated that the bubbly flow dominates the aerated drilling fluid flow in drilling operations. The comprehensive feasibility study of the use of gas lift in the marine riser to maintain the pressure in BOP equal to the hydrostatic pressure of outside seawater was provided by Lopes and Bourgoyne [6]. In their study, fluid properties were assumed to be known and constant over the entire system, and solubility and bubble pressure were not considered in the hydraulic models. Nakagawa et al. [7] described the efforts made by a group of companies that concentrated on using nitrified fluid in deepwater wells from a semisubmersible platform. Further, Nakagawa et al. [8] compared two steady-state and two transient drilling hydraulic simulators for aerated fluids (OBM and WBM) against field data. In one of the steady-state models, they noticed that the gas solubility was allowed without explaining the details of solubility models. Furthermore, in transient models, they just considered the solubility of hydrocarbon gas. Hermann and Shaughnessy [9] proposed a Nitrogen injection and floating mud cap to achieve the dual gradient. Moreover, they introduced a new form of riser gas-lift, which used high pressure, smaller and concentric risers to decrease the injected gas volume in the drilling fluid. They demonstrated that an injection of Nitrogen into a drilling fluid with a density of $16.2 \mathrm{ppg}$ (pound per gallon) could achieve what they called "the magic mud weight" about 6.9 ppg above the seafloor. Perez-Tellez et al. [10] presented an improved mechanistic model for steady-state flows throughout UBD operations and the model including downward and upward two-phase flow. Stanislawek [11] and Smith et al. [12] used OLGA and programmed mathematical models to simulate riser gas lift operations, but they did not consider solubility and bubble pressure.

Gas-lift DGD implements gasified drilling fluid to reduce the equivalent circulating density (ECD). Utilizing fluids with varying density can provide the desired annular pressure by managing ECD, which has such advantages of improving safety and well performance, as well as reducing the casing sizes and non-productive time [13]. Besides, the development of deepwater drilling has led to the increase in the application of oil-based mud (OBM) and synthetic-based drilling fluids. These kinds of drilling fluids have such characteristics as the high rate of penetration, lubricity, shale inhibition, and low toxicity. The drilling in deepwater is complex, and in the case of using OBM instead of waterbased mud (WBM), the conditions become more complicated. All these facts highlight the presence of the well-known question of which model is appropriate for considering solubility and bubble pressure in the study of gas-lift DGD.

Even though many studies have been carried out on OBM and Hydrocarbon gas (Methane), a limited number of research works have been reported on investigating the PVT properties of air or Nitrogen in OBM. A number of researchers have merely mentioned the usage of the solubility model for Nitrogen and OBM without introducing a model or data. One of the earlier studies about Nitrogen and mineral oil was carried out by Dilchert and Kuss [14]. They conducted experiments to determine Nitrogen solubility in mineral oils at pressures up to 14,500 psi. Rommetveit and Olsen [15] studied Nitrogen solubility in OBM and fluid density changes. However, they ignored the composition of base oil and extrapolated PVT data for gas solubility. In Rommetveit and Vefring [16], the data were available for the Nitrogen solubility in OBM at $68 \mathrm{oF}$ for various pressures. They used these data to design a kick simulator. Bassani and Piccigallo [17] discussed the effect of temperature on the solubility of various gases such as Nitrogen, natural gas, air, and carbon dioxide in mineral oil. In addition, some figures about the solubility of air versus pressure for several oils such as mineral, Silicone, and Ester are represented in their work. Tong et al. [18] measured the solubility of Nitrogen in selected n-paraffin hydrocarbons (Decane, Eicosane, Octacosane, Hexatriacontane) by using a static equilibrium cell over temperatures from 122 to $302^{\circ} \mathrm{F}$ at pressures up to $2610 \mathrm{psi}$. They also calculated solubility 
values by Soave-Redlich-Kwong and Peng-Robinson equations of state. The interaction parameter that was used in the equation of state (EOS) was derived from regressing data at desired temperatures. They observed that solubility (mole fraction of Nitrogen) increased by increasing temperature and pressure. Furthermore, the solubility of Nitrogen increased with the chain length of the solvent molecule. Moreover, some studies have been conducted on gas-lift DGD with water-based mud.

As can be seen from the above-mentioned studies, there is no particular study on gas-lift DGD with oil-based mud. In the present study, white mineral oil (\#5) as liquid phase $(\mathrm{OBM})$ and Nitrogen as the gas phase were investigated in gas-lift dual gradient drilling technology. In the case of using an oil-based drilling fluid instead of a water-based one, drilling situations become more complicated. This is because, at the same pressure and the same temperature, the solubility of the gas in an oil-based drilling fluid (OBDF) would be 10-100 times greater than in water-based drilling fluids [19], and OBM is more compressible than WBM. The solubility influences other properties such as density, viscosity, oil volume factor, etc. Therefore, the PVT behavior of gas and OBDF must be understood for calculating pressure, equivalent circulating density, and well control issues. In addition, the bubble pressure in two-phase OBDF is important because density, viscosity, oil volume factor, and other parameters would be different below and above the bubble point pressure (saturated and under-saturated mixture). The solubility of the gas in the OBDF determines the phase behavior of gas in the wellbore. After all, for steady-state wellbore pressure calculations, the solubility and the bubble pressure models are necessary to determine the density, oil volume factor, and viscosity of drilling fluid and eventually calculate the pressure at any position in the annulus.

There are some correlations (equations or relations) for calculating the solubility and bubble point pressure. Thomas et al. [20] stated that "an oil-based mud is treated as an oil with properties as calculated from the Standing correlations". Therefore, Standing's work [21] is perhaps the most widely used tool [22]. The Standing model is one of the conventional Black oil models. Nonetheless, an important question is whether the Standing model is proper for calculating the solubility of Nitrogen in white mineral oil or not. In the case of using the Standing model for the solubility, how much error would happen to the other PVT parameters? Therefore, Negahban et al. [23] conducted some experiments for finding solubility and bubble point of Nitrogen and white mineral oil for temperatures and pressures of deepwater reservoirs in the South China Sea. They used the Constant Composition Expansion (CCE) method for evaluating solubility and bubble pressure of the mixture at mentioned conditions. They finally proposed two equations for solubility and bubble pressure and also found that the Standing model underestimates bubble pressure and overestimates solubility for the mixture of Nitrogen in white mineral oil [23].

With this in mind, in the present study, the two new models of Negahban et al. [23], i.e., the solubility equation and bubble point equation as presented in the upcoming sections, were selected as the starting point of the research. The gap felt in the existing knowledge is the application of these two models to gas-lift dual gradient drilling, examining their effect on the thermodynamic properties of the injected gas and the drilling fluid and comparing the obtained results with the case of using the Standing correlations for solubility and bubble pressure. The studied PVT parameters included formation volume factor, mixture density, volumetric flow rate, mixture velocity and void fraction, mixture viscosity, and mixture friction factor, which are a prerequisite for calculating the bottom hole pressure. It is worth noting that this study focused on the feasibility of implementing oil-based drilling fluid in the gas-lift dual gradient drilling (DGD) in the South China Sea. The main objective of this study is to understand the PVT behavior of Nitrogen, as injected gas, and white mineral oil (\#5) as liquid phase, in the case of using the two new models and the Standing model for solubility and bubble pressure. Consequently, this study aims to apply these PVT parameters for calculating bottom hole pressure and, most importantly, evaluate the impact of different models on optimizing the rate of injected gas. Accordingly, the bottom hole pressure was calculated for two new models and the Standing model. 
Finally, the optimum amount of injected gas in liquid was evaluated and compared using different models, and the results were discussed. The calculation of the PVT parameters was conducted through coding in MATLAB, which included more than ten different codes. For the reader's reference, the developed codes are deposited online on the Mendeley data repository and could be found at https:/ / data.mendeley.com/datasets/rzf53yzvm3/1 (accessed on 26 October 2021) [24].

\section{Study Area}

The current study was carried out to overcome part of the challenges confronted in the gas-lift dual gradient deepwater drilling in the South China Sea. Figure 1 shows the geological location of the South China Sea and the major geological provinces and countries adjacent to it. With regard to the drilling activity in the area, in the drilling location where the dual gradient drilling was implemented, the water depth, the true vertical depth of the well, and the measured depth before the horizontal section drilling were $339.7 \mathrm{~m}$, $1222 \mathrm{~m}$, and $5452 \mathrm{~m}$, respectively [25,26]. Moreover, the density of the seawater, density of drilling fluid, cuttings density, and the density of the drilled formation were $1.03 \mathrm{~g} / \mathrm{cm}^{3}$, $1.11 \mathrm{~g} / \mathrm{cm}^{3}, 2.5 \mathrm{~g} / \mathrm{cm}^{3}$, and $2.18 \mathrm{~g} / \mathrm{cm}^{3}$, respectively $[25,26]$. The liquidity index was 0.5885 , the consistency coefficient was $0.7565 \mathrm{~Pa} . \mathrm{s}^{\mathrm{n}}$, the rate of penetration was $8 \mathrm{~m} / \mathrm{h}$, and the flow rate of the drilling fluid was $40 \mathrm{~L} / \mathrm{s}$. While the bearing capacity equivalent to the offshore drilling method was implemented, the well's extended-reach limit was $8261 \mathrm{~m}$ which became greater when the dual gradient method was applied [25,26].

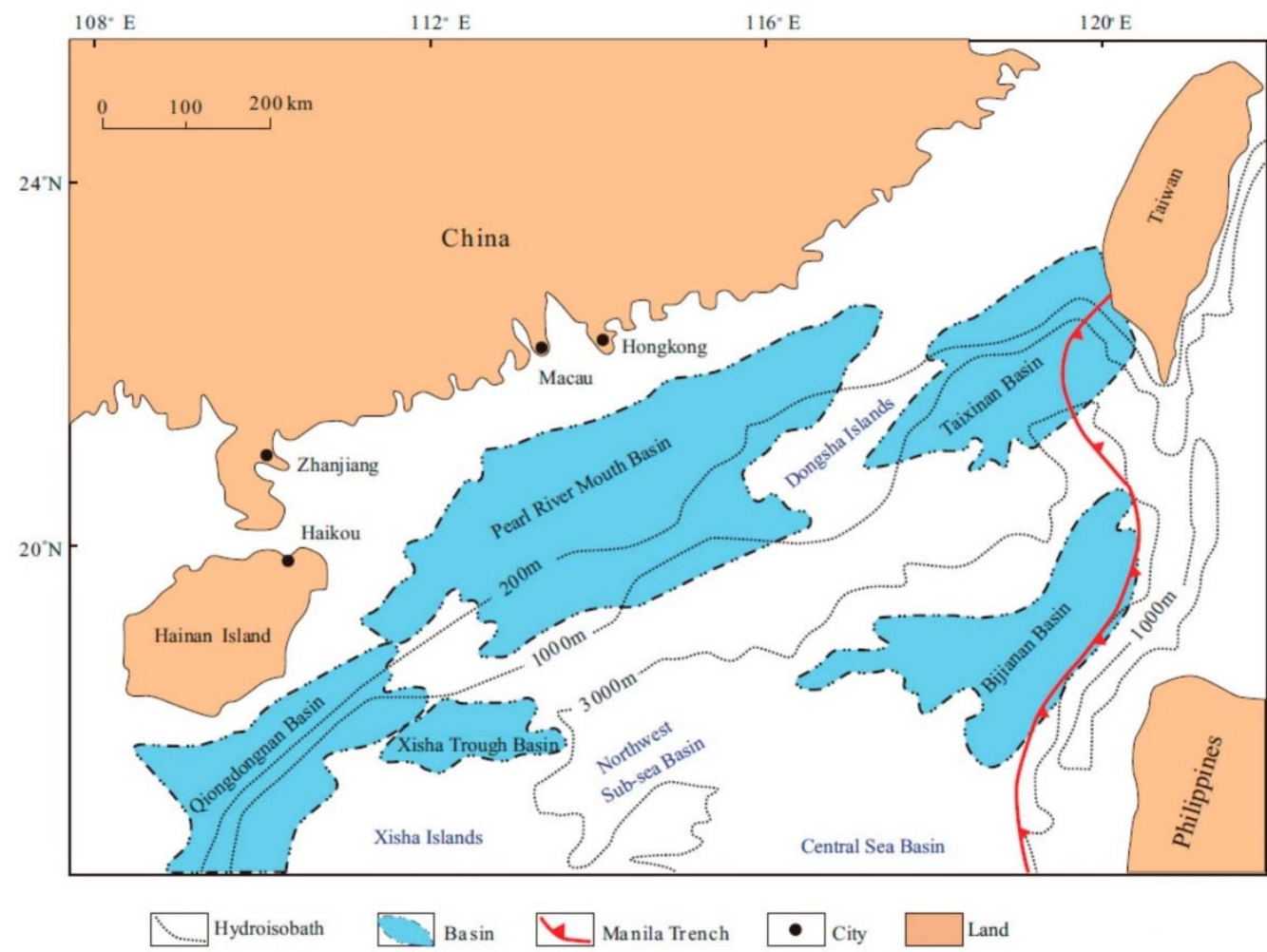

Figure 1. Geological map of the study area modified after Shen et al. [27]. The map shows the major geological provinces and countries nearby the South China Sea.

\section{Materials and Methods: PVT of Two-Phase Flow}

Various types of dual gradient drilling (DGD) techniques are available nowadays. Figure 2 illustrates the DGD methods in the pre-BOP (before installing blowout preventer) and post-BOP (after installing blowout preventer) stages. Estimation of dynamic riser and wellbore pressures during drilling operation depends on such parameters as mud weight, the height of mud column, well and riser geometry, mud viscosity, temperature, etc. In the 
case of injecting Nitrogen in the riser, single flow pressure estimation changes to multi-flow pressure estimation, and this kind of calculation is more complicated. Figure 3a illustrates fluid flow paths for a gas-lift dual gradient system.

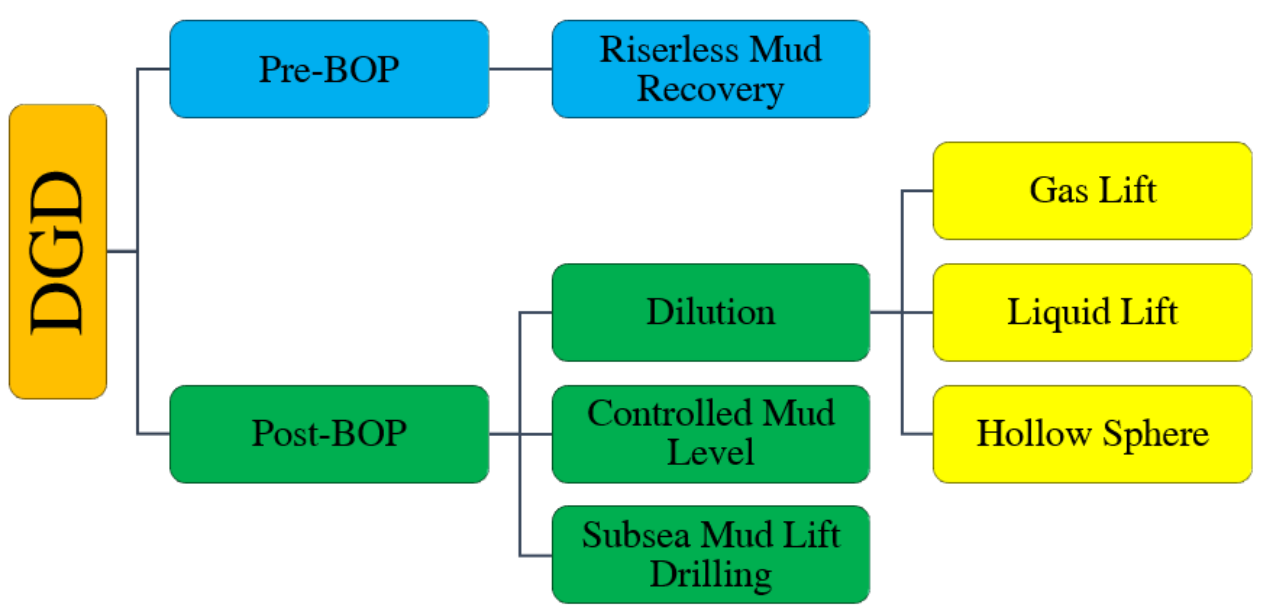

Figure 2. Classification of various dual gradient drilling methods before and after installing blowout preventer.

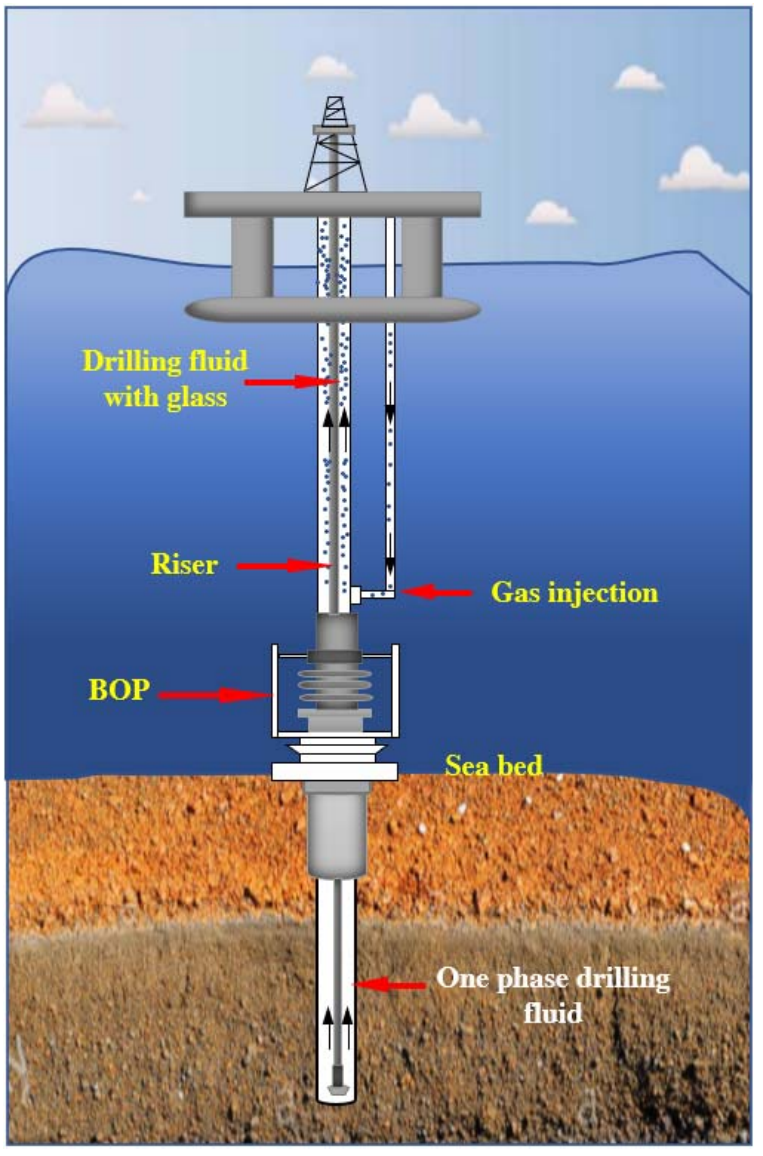

(a)

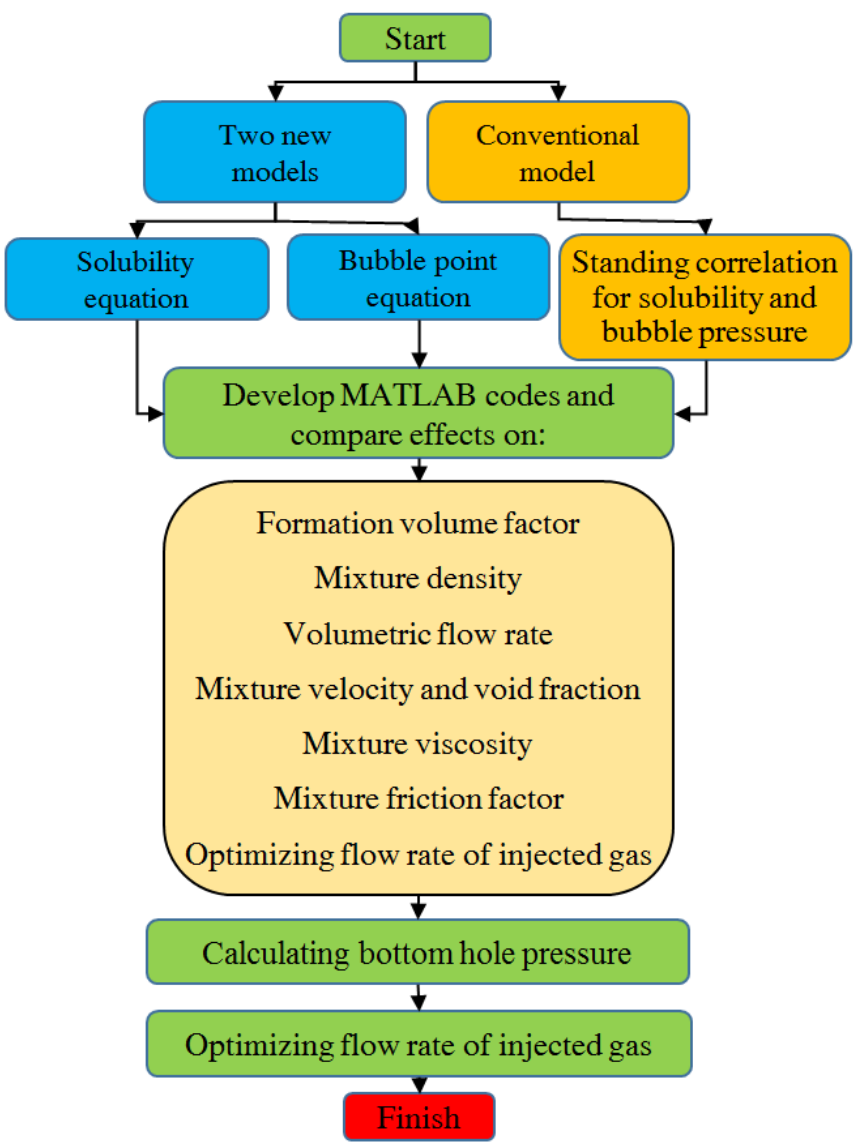

(b)

Figure 3. (a) Schematic representation of the gas-lift DGD, (b) Workflow of the current research. 
First of all, the PVT behavior of the mixture (injected gas plus drilling fluid) should be evaluated precisely by calculating the PVT parameters. As mentioned above, in the present study, the injected gas was Nitrogen, and the drilling fluid was white mineral oil (\#5). Therefore, significant PVT properties were evaluated and compared in the cases of using the two new models and using the Standing correlations at specific temperatures. The two new models are the solubility equation as expressed in relation (1) and the bubble point equation as expressed in relation (2). The calculations were performed through coding in the MATLAB environment, and the corresponding codes are provided for the future reader at the above-mentioned online data repository. Figure $3 \mathrm{~b}$ represents the workflow adopted in the current research study, and Figure 4 shows the detailed workflow that was adopted for coding the calculations in MATLAB.

$$
\begin{gathered}
R_{S}(P, T)=3.084 \times 10^{-2} P-7.231 \times 10^{-3} T+1.964 \times 10^{-6} P^{2}+4.003 \times 10^{-5} P T+1.245 \times 10^{-5} T^{2}+1.62 \\
P_{b}\left(R_{s}, T\right)=30.12 R_{s}-0.21731 T-0.02907 R_{s}{ }^{2}-0.02113 R_{s} T+7.046 \times 10^{-4} T^{2}-5.275
\end{gathered}
$$

where $R_{S}$ is the solution gas-oil ratio (scf/STB), $P$ is the pressure (psi), $T$ is the temperature $\left({ }^{\circ} \mathrm{F}\right)$, and $P_{b}$ indicates the bubble point pressure (psi). These two models, with all their technical details, have already been discussed in the published literature and would be found at Negahban et al. [23]. Nonetheless, the experimental procedure is briefly described as follows. A $370 \mathrm{~cm}^{3}$ single-window PVT cell encased in a heating jacket was used as the experimental cell. The pressure and temperature of this cell could be changed from "atmospheric pressure to $3600 \mathrm{psi}^{\prime \prime}$ and "ambient temperature to $248^{\circ} \mathrm{F}$ ", respectively. The PVT cell and the connections were cleaned properly before conducting the experiment, and the experimental method was constant composition expansion. First of all, the desired amount of $205 \mathrm{~cm}^{3}$ sample oil was charged into the experimental cell as the standard condition, which was followed by gas injection using a precise device. The gas injection device could monitor the temperature of the gas and was appropriately evaluated for its accuracy before the experiment. The oil-Nitrogen mixture was compressed to 3600 psi which made the mixture a single-phase fluid. After several hours, no changes in the equilibrium were observed, indicating that the mixture was fully sutured with Nitrogen gas. At this point, the pressure was slowly decreased until the two-phase mixture was obtained and the bubble point pressure was determined. The experiment ended when the clear bubbles were observed. Herein, the visual observation was adopted for analyzing the bubble pressure, which corresponds to the breakage in the pressure-volume curve. It is worth noting that the stated purity of Nitrogen gas was $99.99+\mathrm{mol} \%$, and C14, C15, and C16 were the main components of the white mineral oil (\#5), which had a density of $816 \mathrm{~kg} / \mathrm{m}^{3}$ at standard conditions. Appendix A section provides further experimental details and the obtained data.

The application of Nitrogen in dual gradient drilling has been reported in previous studies extensively [28-33]. A review of the existing literature reveals that Nitrogen is an inert gas and could be used in the riser for enhancing security, i.e., decreasing the risk of methane explosions in dual gradient drilling [33]. Nitrogen could also be used to reduce the weight of the mud in the riser [31,32], and most considerably, it could be accessed easily for laboratory and field-scale practices because Nitrogen Generation Units (NGU) or Nitrogen Production Units (NPU) produce it from the air using a filtering process. In addition, the solubility of Nitrogen in oil is lower than air and also lower than natural gas. Moreover, the Nitrogen pumpers are gas compressors, and liquid Nitrogen has been implemented in the offshore underbalanced drillings as well [30]. 
Input $\left(q_{g(s c)} \& q_{O(S C l)}\right)$, oil API, and well geometry (total depth \& Di \& Do, temperature gradient, $\Delta z, \varrho_{o(s c)}, T_{s}, P_{s} M_{g}, T_{p c}=227.16 ; P_{p c}=492.9855$

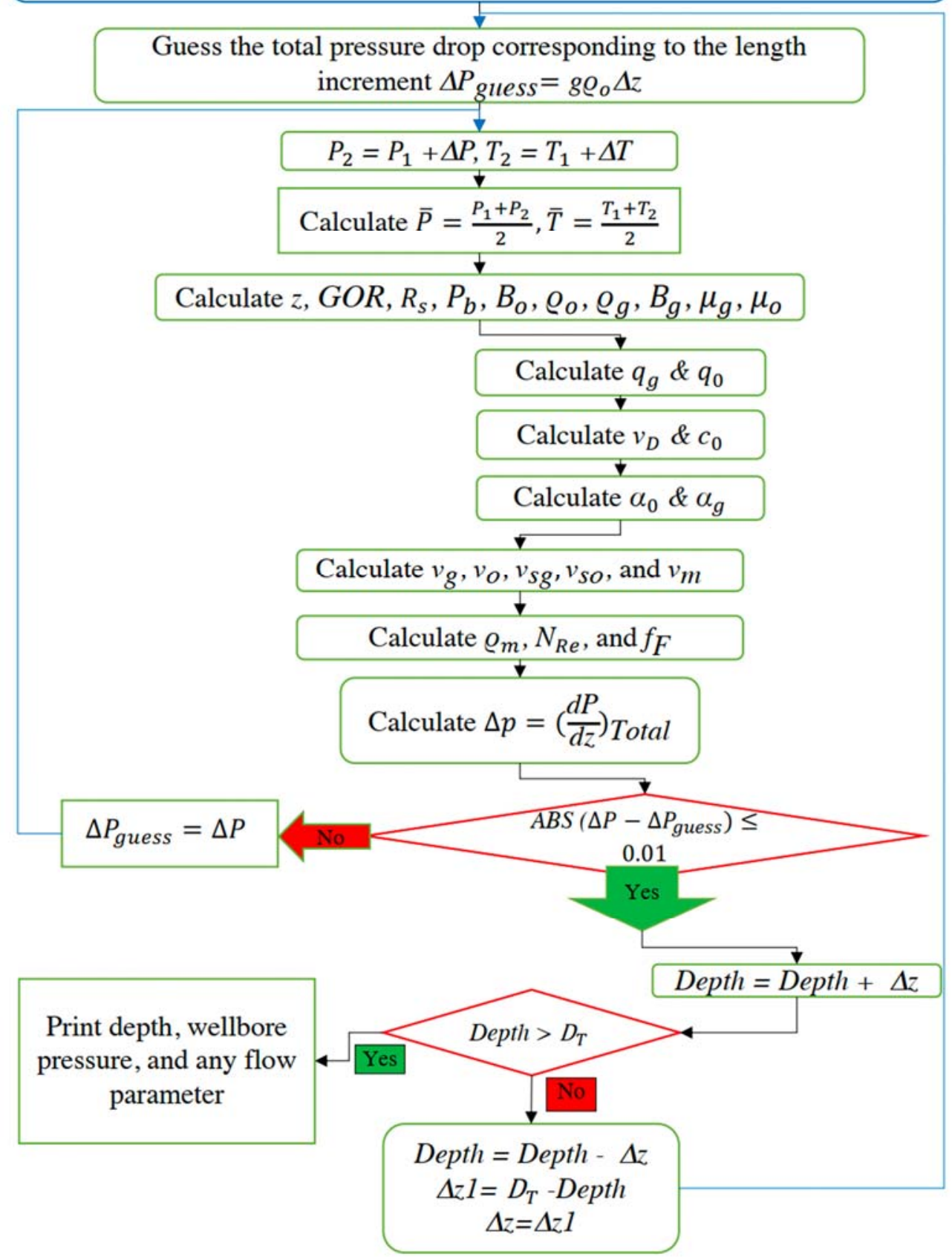

Figure 4. Coding workflow inside MATLAB environment for calculating various PVT properties.

\subsection{Two-Phase Flow Pressure}

Essentially, the Equations (3)-(6) express the steady-state pressure gradient equations for multiple flows, which were derived from conservation of mass and momentum [34]:

$$
\begin{gathered}
\left(\frac{d p}{d z}\right)_{\text {Total }}=\left(\frac{d p}{d z}\right)_{\text {Elevation }}+\left(\frac{d p}{d z}\right)_{\text {Friction }}+\left(\frac{d p}{d z}\right)_{\text {Acceleration }} \\
\left(\frac{d p}{d z}\right)_{\text {Elevation }}=g \rho_{m}
\end{gathered}
$$




$$
\begin{aligned}
\left(\frac{d p}{d z}\right)_{\text {Fricton }} & =\frac{f_{m} \rho_{m} u_{m}^{2}}{2 D_{h}} \\
\left(\frac{d p}{d z}\right)_{\text {Accleration }} & =\rho_{m} u_{m} \frac{d u_{m}}{d z}
\end{aligned}
$$

where $p$ : pressure (psi); $z$ : distance $(\mathrm{ft}), \rho_{m}$ : mixture density $\left(\mathrm{lbm} / \mathrm{ft}^{3}\right), f_{m}$ : mixture friction factor, $u_{m}$ : mixture velocity (ft/s), and $D_{h}$ : hydraulic diameter (ft), and $g$ : gravitational acceleration constant equal to $32.17 \mathrm{ft} / \mathrm{s}^{2}$.

In the case of using OBM and Nitrogen mixture as drilling fluid or mud in the drilling well, for evaluating pressure gradient equations' accurately, mixture density $\left(\rho_{m}\right)$, mixture velocity $\left(u_{m}\right)$, and friction factor should be calculated considering the solubility and bubble point pressure. In the following sections, the effect of the Standing correlations and the new solubility and bubble pressure models on the calculation of these thermodynamic properties will be discussed. Table 1 indicates the constant values used in the calculations of the present study.

Table 1. Values of the constant parameters in the calculation of the different PVT values.

\begin{tabular}{ll}
\hline Input Parameter & Value \\
\hline Riser depth & $6000 \mathrm{ft}$ \\
Surface temperature & $68\left({ }^{\circ} \mathrm{F}\right)$ \\
Temperature gradient & $1.6\left({ }^{\circ} \mathrm{F} / 100 \mathrm{ft}\right)$ \\
Surface (back) pressure & $200(\mathrm{psi})$ \\
Base oil density & $41(\mathrm{API})$ \\
Base oil viscosity & $5.34(\mathrm{MPa} . \mathrm{s})$ \\
Producing gas-liquid ratio & $300(\mathrm{scf} / \mathrm{stb})$ \\
Water cut & $20(\%)$ \\
Drill-string outer diameter & $5.5(\mathrm{inch})$ \\
Riser inner diameter & $17.5(\mathrm{inch})$ \\
Liquid flow rate at standard condition & $500 \mathrm{gpm}$ \\
Oil flow rate at standard condition & $\mathrm{gpm}$ \\
Gravitational acceleration constant & $32.17 \mathrm{ft} / \mathrm{s}^{2}$ \\
\hline
\end{tabular}

\subsection{Determination of Formation Volume Factor (FVF)}

Some PVT properties depend on gas and liquid formation volume factor (FVF). After evaluating the gas compressibility factor $(Z)$, solubility and bubble pressure, the gas and liquid $F V F$ are prerequisite parameters that should be calculated. Gas formation volume factor (cuft/scf) (cubic feet/standard cubic feet) has the following form:

$$
B_{g}=\frac{P_{s c} T}{P T_{s c}} Z=\frac{14.7(T+459.67)}{P 519.67} Z
$$

where $B_{g}$ : gas formation volume factor $\left(\mathrm{ft}^{3} / \mathrm{scf}\right), P_{s c}$ : standard pressure (psi), $T_{s c}$ : standard temperature $\left({ }^{\circ} \mathrm{R}\right)$, and $Z$ : gas compressibility factor.

The gas compressibility factor, $Z$, must be known in Equation (7). Among the available empirical correlations to determine gas compressibility factor, the Dranchuk and AbouKassem [35] correlation is more popular in drilling.

The McCain correlation [36] was used to estimate the water formation volume factor $\left(B_{w}\right)$ at different pressures and temperatures as:

$$
B_{W}=\left(1+\Delta V_{W P}\right)\left(1+\Delta V_{W T}\right)
$$

where $B_{w}$ indicates the water formation volume factor (bbl/STB) and:

$$
\Delta V_{W P}=-1.0001 \times 10^{-2}+1.33391 \times 10^{-4} T+5.50654 \times 10^{-7} \times T^{2}
$$




$$
\Delta V_{W P}=-1.95301 \times 10^{-9} P T-1.72834 \times 10^{-13} P^{2} T-3.58922 \times 10^{-7} \times P-2.25341 \times 10^{-10} P^{2}
$$

The oil formation volume factor could be determined by experiment or could be estimated by the available Black oil models. Below the bubble point pressure (saturated $F V F)$, the equation has the following form [21]:

$$
B_{O}=0.972+0.000147\left(R_{S}\left(\frac{\gamma_{g}}{\gamma_{o}}\right)^{0.5}+1.25 T\right)^{1.175}
$$

where $B_{0}$ : oil formation volume factor (bbl/STB), $\gamma_{o}$ : Specific gravity of the stock-tank oil, $60^{\circ} / 60^{\circ}$, and $\gamma_{g}$ : specific gravity of the solution gas.

The general equation for oil FVF above bubble point (undersaturated FVF) is:

$$
B_{O}=B_{o b} \exp \left(C_{O}\left(P-P_{b}\right)\right)
$$

where $B_{o b}$ : formation volume factor at bubble point (bbl/STB), $C_{O}$ : oil compressibility $\left(\mathrm{psi}^{-1}\right)$, and the Elsharkawy correlation (Equation (11)) can be used as the oil compressibility $\left(C_{O}\right)[37]:$

$$
C_{O}=\frac{-27321+33.784 R_{S}+238.81 T}{10^{6} P}
$$

Therefore, the oil FVF is a function of pressure, temperature, solubility and, bubble point pressure. Figure 5 shows the calculated oil FVF at three temperatures and different pressures for the new models and the Standing model solubility and bubble point pressure. It is worth mentioning that the shrinkage and swelling of the oil (the main component of oil-based drilling fluid) was considered in the oil formation volume factor $\left(B_{o}\right)$. The formation volume factor $(F V F)$ (oil $F V F$, gas $F V F$, and Total $F V F$ ) is one of the important parameters when calculating the PVT characteristics of two-phase flow.

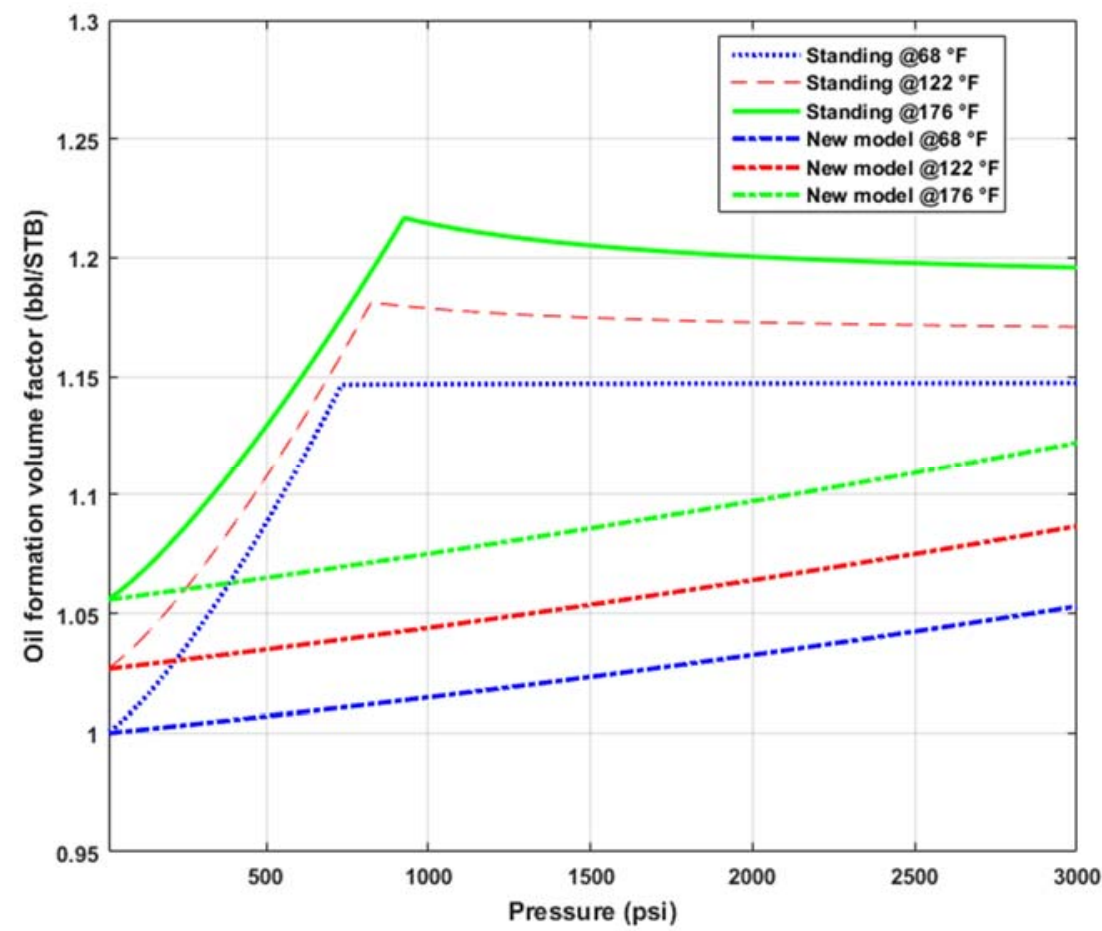

Figure 5. Oil FVF as a function of Standing oil and the new correlations.

In Figure 5, the upper three curves show the results obtained by using the Standing model, and the lower three ones indicate the result obtained by the new models. The inclination point (sudden break in the curves) indicates the bubble point pressure, which 
occurred at the range of (700-1000) psi for three studied temperatures of 68,122 , and $176^{\circ} \mathrm{F}$. However, the bubble point pressure did not appear on the resultant curves of the new models even before a pressure value as high as 3000 psi. This is because the Standing model underestimates the bubble point pressure for the particular mixture of "Nitrogen and white mineral oil (\#5)" examined in the present study and yields a smaller value than the one obtained with the new model (Equation (2)). Meanwhile, according to Equations (9) and (10), the formation volume factor of oil $\left(B_{0}\right)$ is a function of solubility and bubble point pressure.

\subsection{Determination of Mixture Density}

Equation (12) represents gas (Nitrogen) and liquid (mineral oil and water) mixture density [38]:

$$
\rho_{m}=\rho_{L} H_{L}+\rho_{g}\left(1-H_{L}\right)
$$

where $H_{L}$ : liquid holdup, $\rho_{m}$ : mixture density $\left(\mathrm{lbm} / \mathrm{ft}^{3}\right), \rho_{L}$ : liquid density $\left(\mathrm{lbm} / \mathrm{ft}^{3}\right)$, and $\rho_{g}$ : gas density $\left(\mathrm{lbm} / \mathrm{ft}^{3}\right)$. as [38]:

The gas density is a function of gas $F V F$, and the liquid density $(\rho l)$ and is defined

$$
\rho_{l}=f_{o} \rho_{o}+f_{w} \rho_{w}
$$

where $f_{o}$ and $f_{w}$ are the oil, and water volume fractions, respectively. Equations (14) and (15) represent water and oil density at different pressures and temperatures [38]:

$$
\begin{gathered}
\rho_{o}=\frac{62.4 \gamma_{o(s c)}+\frac{0.0764 \gamma_{g(s c)} R_{s(P, T)}}{5.615}}{B_{o\left(P, T, R_{s}\right)}} \\
\rho_{w}=\frac{62.4 \gamma_{w(s c)}}{B_{w(P, T,)}}
\end{gathered}
$$

where $\rho_{o}$ : oil density $\left(\mathrm{lbm} / \mathrm{ft}^{3}\right), \rho_{w}$ : water density $\left(\mathrm{lbm} / \mathrm{ft}^{3}\right), \gamma_{o(s c)}$ : specific gravity of oil at standard condition, $\gamma_{g(s c)}$ : specific gravity of the solution gas at standard condition, and $\gamma_{w(s c)}$ : specific gravity of water at standard condition.

The mixture density is a function of oil density, and according to Equation (14), oil density depends on oil and gas gravity at standard condition, solubility, and oil FVF. Figure 6 indicates the oil density as a function of Black oil and the new models.

Again, as can be seen from Figure 6, since the bubble point pressure obtained from the Standing model is underestimated for the studied mixture of Nitrogen and white mineral oil (\#5), the breakage in the curves resulting from the Standing model could be observed at the range of (700-1000) psi for three studied temperatures of 68,122 , and $176^{\circ} \mathrm{F}$ while it did not happen for the pressures obtained from the new models in less than 3000 psi.

\subsection{Determination of Volumetric Flow Rate}

The Equations (16) and (17) represent the in-situ gas and liquid flow rate, respectively [38]:

$$
\begin{gathered}
q_{g}=\frac{q_{g(s c)}\left(G O R-R_{s}\right) B_{g}}{2600 \times 24} \\
q_{l}=q_{o}+q_{w}=6.49 \times 10^{-5}\left(q_{o(s c)} B_{o}+q_{w(s c)} B w\right)
\end{gathered}
$$

where: GOR: gas-liquid ratio (scf/STB), $q_{g(s c)}$ : gas flow rate at standard condition (scf/s)

$q_{o(s c)}:$ oil flow rate at standard condition (scf/s), $q_{w(s c)}$ : water flow rate at standard condition (scf/s)

$q_{w}$ : in-situ water flow rate $\left(\mathrm{ft}^{3} / \mathrm{s}\right), q_{l}$ : in-situ liquid flow rate $\left(\mathrm{ft}^{3} / \mathrm{s}\right), q_{g}$ : in-situ gas flow rate $\left(\mathrm{ft}^{3} / \mathrm{s}\right)$, and

$q_{o}$ : in-situ oil flow rate $\left(\mathrm{ft}^{3} / \mathrm{s}\right)$.

According to these relations, the oil flow rate is a function of oil FVF directly. Since the oil FVF depends on the bubble point and solubility, therefore, the oil flow rate also depends 
on solubility and bubble point. Figure 7 compares oil flow rate in the case of using the new models versus using the Standing model for solubility and bubble pressure.

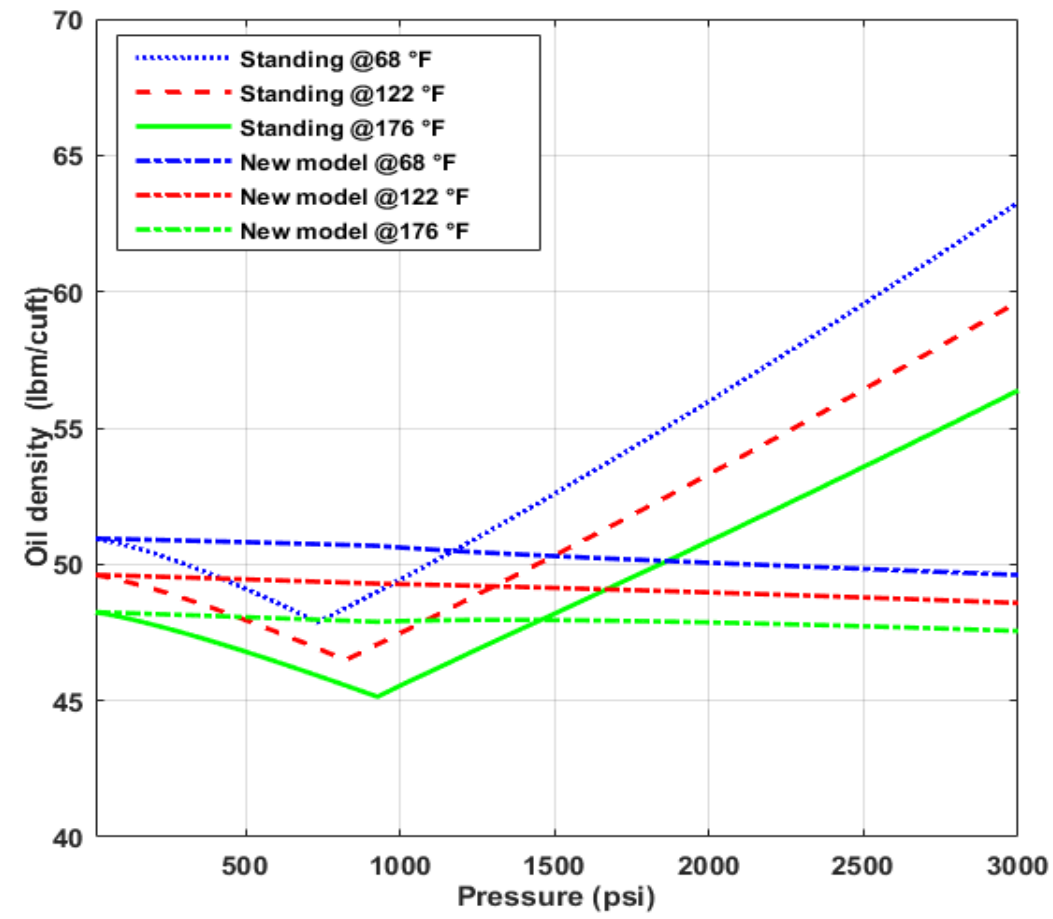

Figure 6. Oil density as a function of Black oil and the new correlations.

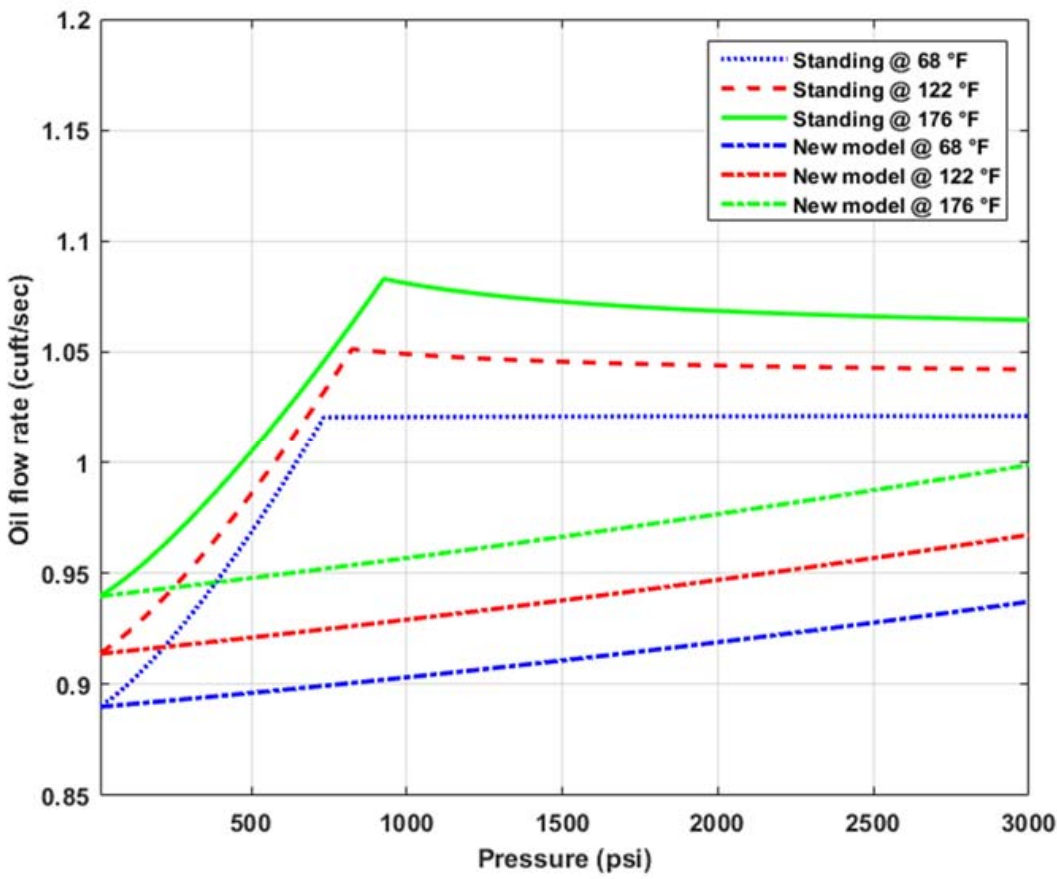

Figure 7. Oil flow rate as a function of Black oil and the new correlations.

With regard to Figure 7, it should be noted that as mentioned inside Equation (17), in-situ oil flow rate $\left(q_{o}\right)$ is a function of oil flow rate at standard condition $\left(q_{o(s c)}\right)$ multiplied by the oil formation volume factor $\left(B_{0}\right)$. The oil formation volume factor was presented and discussed in Figure 5, and therefore, the same phenomenon of underestimating the bubble point pressure for the studied mixture of Nitrogen and white mineral oil (\#5) by the Standing model is observed. 


\subsection{Determination of Mixture Velocity and Void Fraction}

Estimation of liquid and gas mixture velocity and void fraction are crucial steps in the multiphase flow pressure calculation. In addition, according to relations (5) and (6), the friction pressure and acceleration pressure directly depend on mixture velocity. Moreover, the void fraction $(\alpha)$ or its corresponding parameter liquid-holdup $(1-\alpha)$ are applicable in some PVT parameters estimation. There are a lot of methods or theories for finding these two parameters, among which the Drift Flux theory is a very appropriate method. This theory was stated by Zuber and Findlay [39]. Drift Flux calculations are faster than the mechanical model, and its results are more accurate than the homogenous model (phases with the same velocity). In this study, two important parameters of Drift Flux, that is, the distribution parameter $\left(c_{0}\right)$ and the drift velocity $\left(v_{D}\right)$, were selected as Equations (18) and (19) [40]:

$$
\begin{gathered}
c_{0}=1.2 \\
V_{D}=\left(0.345+0.1 D_{i} / D_{o}\right) \sqrt{g\left(\rho_{l}-\rho_{g}\right) D_{o} / \rho_{l}}
\end{gathered}
$$

where $c_{0}$ : distribution parameter, $v_{D}$ : drift velocity $(\mathrm{ft} / \mathrm{s}), D_{i}$ : well internal diameter (inch), and $D_{o}$ : drill-string outer diameter (inch). Finally, by using the above relations, the mixture velocity and void fraction could be calculated by Equations (20) and (21):

$$
\begin{gathered}
\alpha_{g}=\left(1-H_{L}\right)=\frac{v_{s g}}{\left(c_{0}+v_{m}\right)+v_{d}} \\
v_{m}=v_{s g}+v_{s l}=\frac{q_{g}}{A}+\frac{q_{l}}{A}
\end{gathered}
$$

where $\alpha_{g}$ : void fraction, $V_{s g}$ : gas superficial velocity (ft/s), $V_{s l}$ : liquid superficial velocity $(\mathrm{ft} / \mathrm{s})$, and $A$ : cross-sectional area of the flow $\left(\mathrm{ft}^{2}\right)$. The void fraction, liquid holdup, and mixture velocity are a function of flow rate. Furthermore, as represented in Equations (17) and (18), the flow rate depends on bubble pressure and solubility. For instance, the void fractions at different depths are depicted in Figure 8.

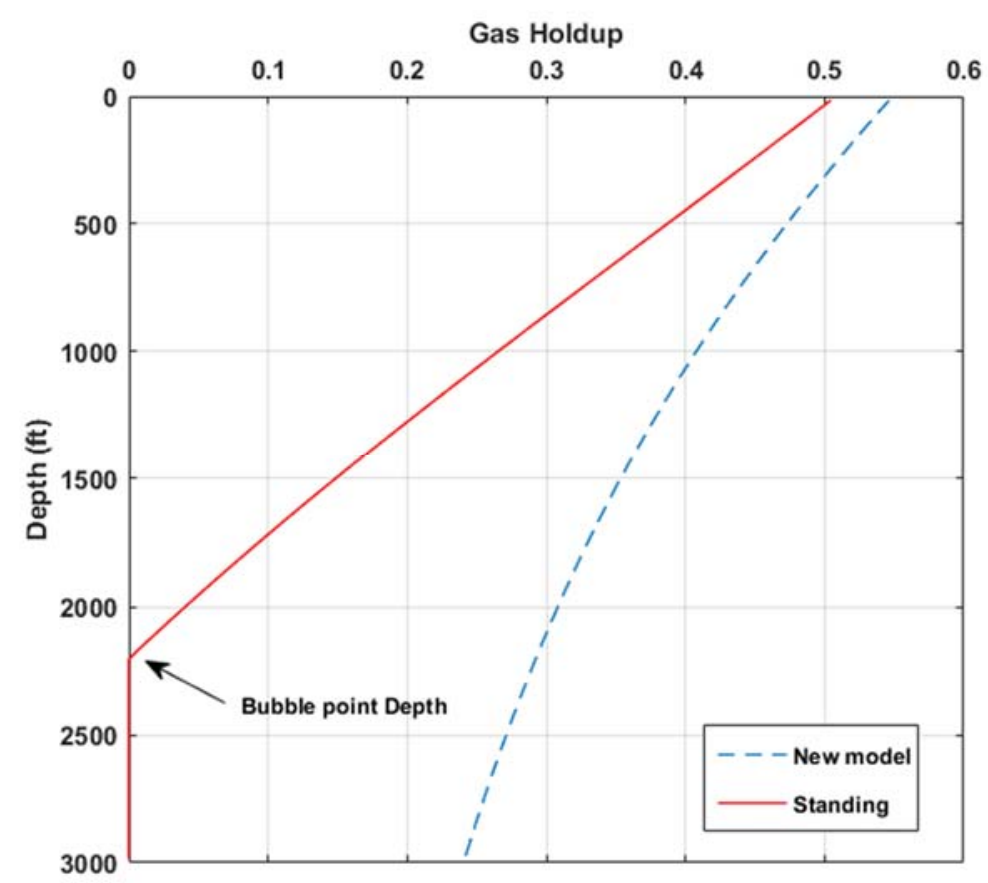

Figure 8. Gas holdup versus depth, as a function of Standing and the new correlations. 


\subsection{Determination of Mixture Viscosity}

The first step in calculating mixture viscosity is determining the gas viscosity and the liquid (oil and gas mixture) viscosity. The Lee correlation is popular for finding gas viscosity [41]. Nevertheless, the liquid phase viscosity could be obtained from Equation (22).

$$
\mu_{l}=f_{o} \mu_{o}+f_{w} \mu_{w}
$$

where $\mu_{o}$ : oil viscosity (cp), $\mu_{w}$ : water viscosity (cp), and $\mu_{l}$ : liquid viscosity (cp).

Therefore, the water and oil viscosity should be calculated. Since the viscosity mostly depends on temperature than pressure variations, the relation (23) represents the water viscosity [42].

$$
\mu_{w}=\exp \left(1.003-1.479 \times 10^{-2} \mathrm{~T}+1.982 \times 10^{-5} \mathrm{~T}^{2}\right)
$$

There are some correlations such as the Black oil model for calculating the oil viscosity in which oil viscosity is significantly different below and above the bubble pressure. In relation (24a) to (24d), Beggs and Robinson proposed a model for calculating saturated oil viscosity (at pressures below bubble point) [42].

$$
\mu_{o\left(P<P_{b}\right)=A\left(10^{x}-1.0\right)^{B}}
$$

where:

$$
\begin{gathered}
x=T^{-1.163} \exp (6.9824-0.04658(A P I)-1.0)^{B} \\
A=10.715\left(R_{S}+100\right)^{-0.515} \\
B=5.44\left(R_{S}+100\right)^{-0.338}
\end{gathered}
$$

In Figure 8, an important concept in drilling, the "bubble point depth", could be observed and evaluated. The bubble point depth has been reported in a very limited number of studies. It is the specific depth during drilling in which the first bubble comes out from drilling fluid; therefore, the mud below this point is one-phase (liquid) which solves the gas as much as possible, and the mud above this point is a mixture of liquid and gas bubbles. Consequently, selecting proper bubble pressure and solubility model plays a crucial role in finding the bubble point depth in drilling engineering. Herein, the bubble point depth obtained with the Standing model is $\approx 2200 \mathrm{ft}$, but the one obtained with the new model (relation (2)) would be at depths higher than $3000 \mathrm{ft}$, which is also caused by the underestimation of the bubble point pressure for the particular mixture of "Nitrogen and white mineral oil (\#5)" by the Standing model.

Moreover, while estimating the pressure of the two-phase flow, the liquid holdup (or void fraction) is a crucial parameter according to relations (4) and (12). On the other hand, the mixture density $\left(\rho_{m}\right)$ is a function of liquid holdup and the void fraction (relation (12)). As the void fraction increases, the liquid holdup and mixture density decrease. Consequently, according to relation (4), as the mixture density $\left(\rho_{m}\right)$ decreases, the elevation pressure decreases as well. Since the major part of the total pressure (about $80 \%$ ) is due to the elevation pressure, the total pressure decreases significantly.

Equation $(25 a, b)$ expresses the undersaturated oil viscosity (at pressures above the bubble point) [43].

$$
\mu_{\left.o(P\rangle P_{b}\right)}=\mu_{o\left(P\left\langle P_{b}\right)\right.} \times\left(\frac{P}{P_{b}}\right)^{m}
$$

where:

$$
m=2.6 P^{1.187} \exp \left(-11.513-\left(8.98 \times 10^{-5}\right) P\right)
$$

In addition, with the assumption of homogenous and nonhomogeneous, the mixture viscosity is divided into two groups, respectively being "no-slip viscosity for same phase velocity" (Equation (27)) and "slip viscosity for phase with different viscosity (Equation (26))":

$$
\mu_{s}=\mu_{l}{ }^{H_{l}}+\mu_{g}{ }^{H g}
$$




$$
\mu_{n}=\lambda_{l} \mu_{l}+\lambda_{g} \mu_{g}
$$

where $\mu_{s}$ : slip viscosity (cp), $\mu_{n}$ : no-slip viscosity (cp), $H_{g}$ : gas holdup, $\lambda_{l}$ : no-slip liquid holdup, and $\lambda_{g}$ : no-slip gas holdup.

According to preceding relations for viscosity, the oil viscosity is a function of bubble point and solubility of the gas in the oil. Figure 9 shows the oil viscosity as a function of the Standing correlations and the two new models.

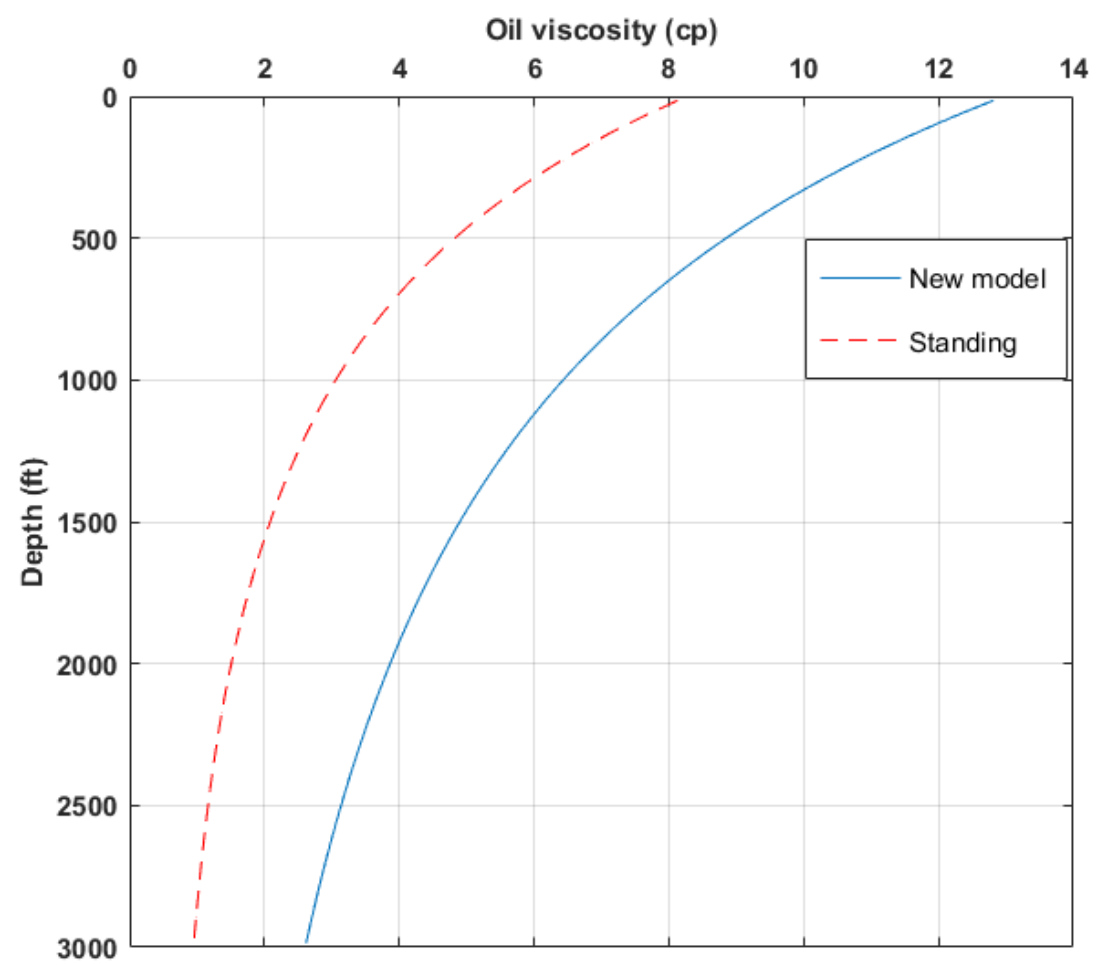

Figure 9. Oil viscosity as a function of Standing model and the new correlations.

As can be seen from Figure 9, a difference of about $2-4 \mathrm{cp}$ is observed for oil viscosity at different sections of the two curves obtained using the Standing model and the new models. It should be mentioned that this much difference is not too much for a drilling fluid property, and this discrepancy is the due effect of solubility in viscosity calculations. The solubility has a reverse effect on viscosity (by increasing solubility, the viscosity decreases as expressed in Equation (24)). Since the Standing model overestimates the solubility of the gas in the oil, as mentioned earlier, the oil viscosity has a lower valve in the case of using Standing correlation for solubility in Equation (24).

\subsection{Determination of Mixture Friction Factor}

For determining the mixture friction factor, various correlations and approaches are available in multiphase flow. The Beggs and Brill models, which were modified for nonNewtonian fluid, are conventional for calculating frictional pressure drop and friction factor in the multiphase flow of drilling fluids [44]. Accordingly, Equations (28), (29) and (31) were respectively used for finding friction pressure drop, no-slip Reynolds Number, and friction factor for the mixture of liquid and gas [44].

$$
\begin{gathered}
\left(\frac{d p}{d z}\right)_{\text {Fricton }}=\frac{f_{m} \rho_{n} u_{m}^{2}}{2 D_{h}} \\
N_{\mathrm{Re}, n}=1488 \frac{\rho_{n} u_{m} D_{h}}{\lambda_{l} \mu_{l}+\left(1-\lambda_{l}\right) \mu_{g}}
\end{gathered}
$$




$$
\begin{array}{r}
f_{n}=1488 \frac{1}{\left(2 \log _{10}\left(\frac{N_{\mathrm{Re}, n}}{4.5223 \log _{10}\left(N_{\mathrm{Re}, n}\right)-3.8215}\right)\right)^{2}} \\
\rho_{n}=\rho_{l} \lambda_{l}+\rho_{g}\left(1-\lambda_{l}\right)
\end{array}
$$

where:

$\rho_{n}$ : no-slip density $\left(\mathrm{lbm} / \mathrm{ft}^{3}\right)$, and $N_{\mathrm{Re}, n}$ : no-slip Reynolds number, and

$$
\begin{gathered}
y=\frac{\lambda_{l}}{H_{l}{ }^{2}} \\
y_{1}=\ln (y)
\end{gathered}
$$

If $1<y<1.2$ then

$$
S=\ln (2.2 y-1.2)
$$

Else:

$$
\begin{gathered}
S=\frac{y_{1}}{-0.523+3.182 y_{1}-0.8725 y_{1}{ }^{2}+0.01853 y_{1}{ }^{4}} \\
f_{m}=f_{n} e^{S}
\end{gathered}
$$

where $f_{m}$ indicates the mixture friction factor.

These relations representing friction factor and friction pressure drop are a function of the liquid and gas phase's velocity, viscosity, and liquid holdup (or void fraction). As mentioned before, these parameters depend on the solubility of the gas in oil and the bubble pressure. Accordingly, similar to the parameters in the previous sections, choosing the proper model for solubility and bubble point has obtained a direct effect on friction factor and friction pressure drop.

After finding all PVT properties, by using Equation (3), the total pressure was calculated in MATLAB.

\subsection{Optimizing Flow Rate of Injected Gas}

In conventional drilling, the limitations of feasibilities as well as the capacity of removing cuttings determine the lower boundary or minimum value of liquid rate. On the other hand, the upper boundary is regulated by equivalent circulating density (ECD). Besides considering facilities limitations in drilling operation, the hole cleaning is the lower limit for liquid injection rate, and the maximum ECD which can cause circulation loss is the upper limit for liquid injection rate. These ideas are graphically illustrated in Figure 10, where the upper and lower limits for liquid flow rate are shown.

One of the important issues in designing the aerated drilling operations and gas-lift dual gradient drilling is determining the optimum gas injection rate, i.e., optimizing the flow rate of the injected gas. The steady-state model can predict hydrostatic-dominated and friction-dominated areas in the well. The optimum gas injection rate lies within the boundaries between these two domains. The hydrostatic dominated area occurs when the gas is injected into drilling fluid, and bottom-hole pressure rapidly decreases; while the gas injecting rate increases more, the friction pressure becomes more than hydrostatic pressure, and this region is called the friction-dominated area. Besides, in gas lift dual gradient drilling, optimizing the flow rate of injected gas is a key parameter for controlling the loss or kick problems. The effect of new models and the Standing correlations on the optimum gas injection rate is shown in Figure 11 for 5000 and 20,000 standard barrels per day (146 and $583 \mathrm{gpm})$. 


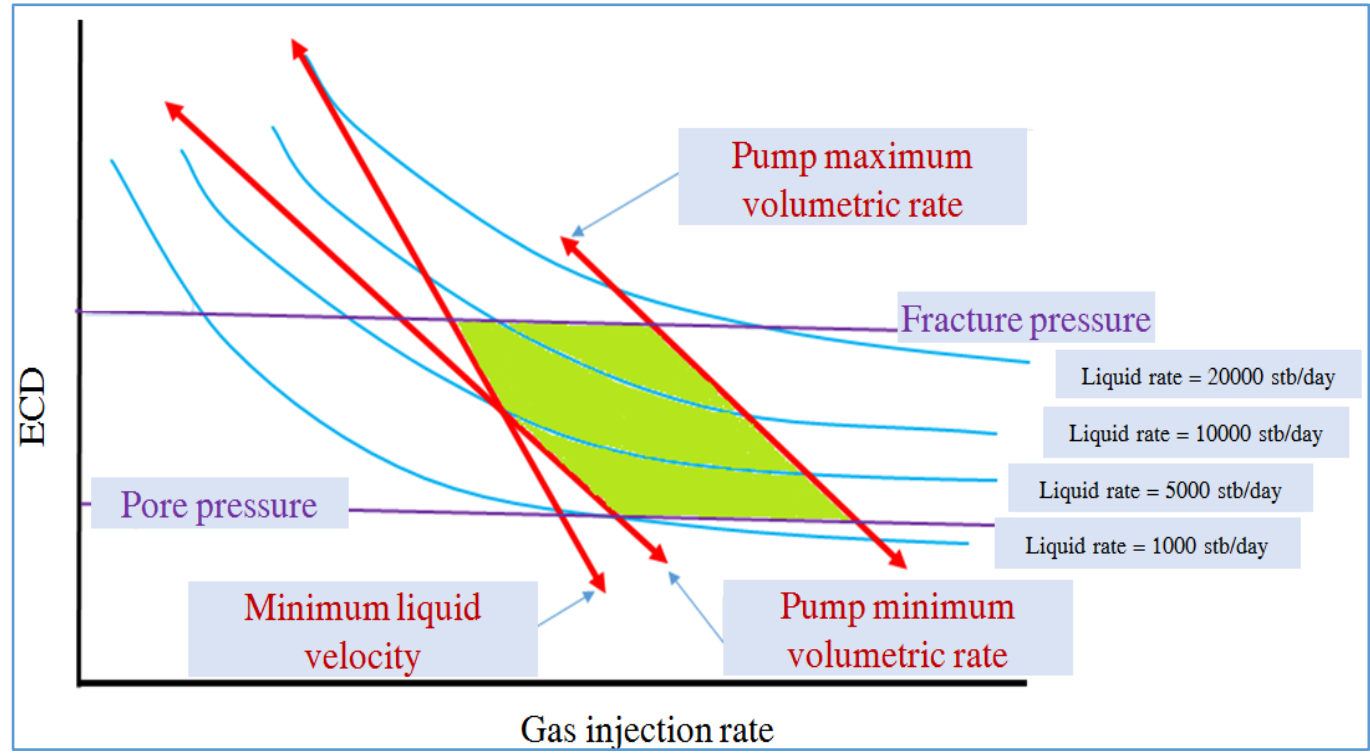

Figure 10. Schematic illustration of the optimal gas injection rate limits. The green area shows the optimum rate domain for gas injection.

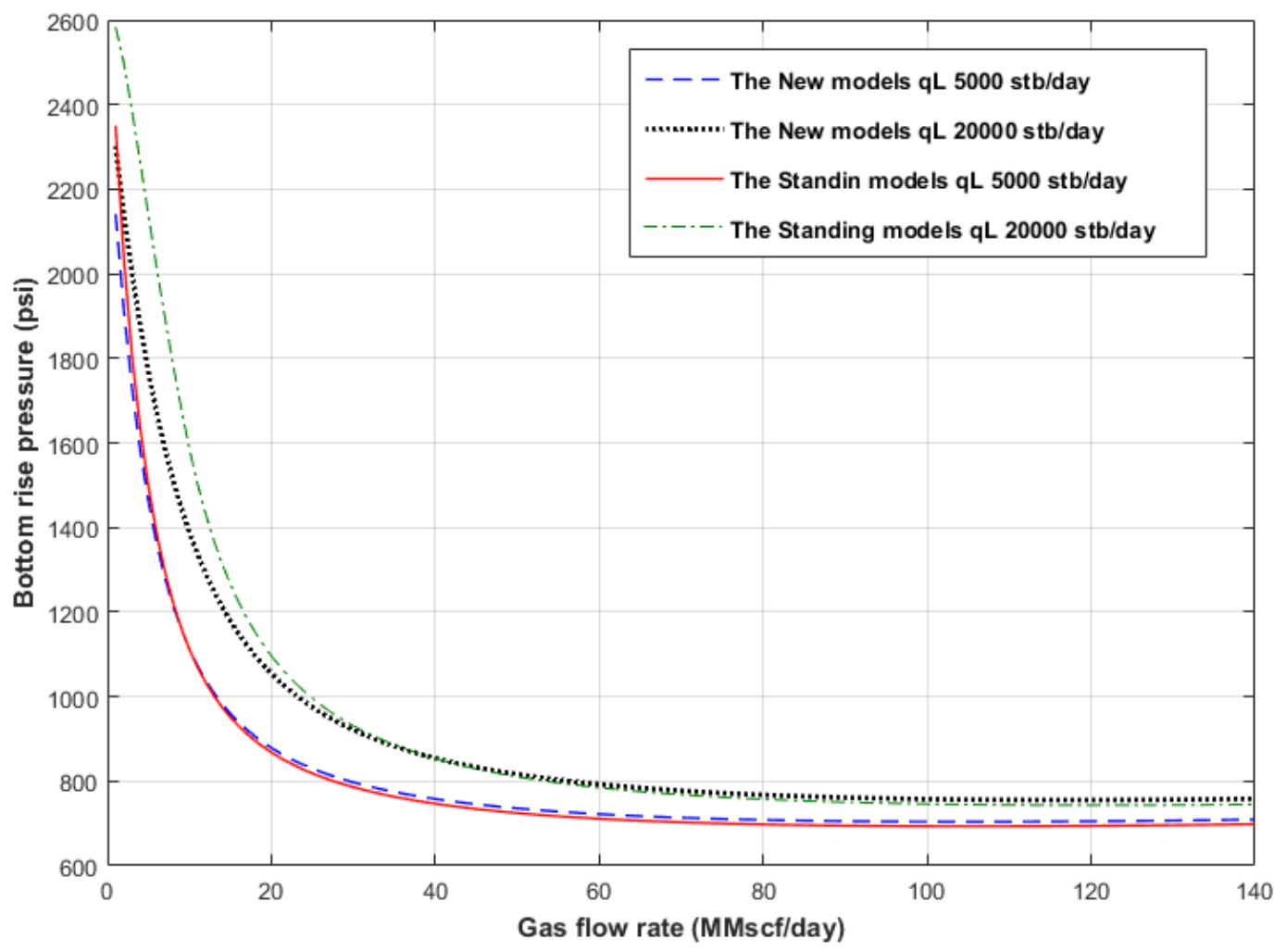

Figure 11. Simulation of bottom hole pressure versus gas injection rate for the new models and the Standing correlations.

There are three parameters represented in Figure 11, and their interconnection needs to be clearly understood in order to better comprehend the phenomena observed in this figure. They are bottom hole pressure on the $Y$-axis, gas injection rate on the $X$-axis, and liquid flow rate, which has two forms of low (5000 stb/day) and high (20,000 stb/day). The low fluid flow rate is indicated by the solid red and dashed blued curves, and the high liquid flow rate is indicated by the dotted black and dash-dotted green curves. Therefore, 
taking the liquid flow rate as the base of interpretation, we will interpret the changes in pressure based on the changes of gas injection rate. As can be seen from this figure, the hydrostatic-dominated area falls in the range of about (0-40) MMSCF/day of gas injection, and the friction-dominated areas fall in the range of more than $40 \mathrm{MMSCF} /$ day of gas injection. There is a good agreement between the results obtained from the Standing model and the new models in the friction-dominated area at both low and high liquid flow rates. In the hydrostatic-dominated area, there is also a good agreement between the results obtained from the Standing model and the new model at low liquid flow rates. However, in this domain, some difference is observed between the two models at high liquid flow rates, for which the underlying facts are as follows. At high liquid flow rates in the hydrostaticdominated area, the Standing model yields higher pressure values compared to the new model. The reason for this phenomenon is that at a high liquid flow rate $(20,000 \mathrm{stb} /$ day compared to $5000 \mathrm{stb} /$ day), the solubility of the gas in liquid plays a much more significant role and shows a more obvious impact on the obtained pressure value. Since the solubility obtained by the Standing model is different from that of the new model for the studied mixture, the two curves tend to show different values of pressure. The difference in pressure values of the two models is because of the difference in the PVT parameters calculation. And since the PVT parameters for the new models were specifically studied for a particular mixture in this study, i.e., "Nitrogen and white mineral oil (\#5)", the resultant values are different as expected. We do believe that since all the fundamental calculations conducted in the present study were particularly for the mentioned fluid mixture, the new model would be more reliable in the case of using this mixture as the drilling fluid. Furthermore, according to Figure 7, the value of the void fraction (gas holdup) obtained from the Standing model is smaller than the void fraction obtained from the new model. As standing underestimates void fraction for the studied mixture of "Nitrogen and white mineral oil (\#5)", mixture density obtained from the Standing model is more than that obtained from the new models. A higher mixture density would lead to a higher bottom hole pressure, as follows from this figure.

\section{Discussion}

Based on the calculated values of oil FVF at temperatures of 68,122 , and $176^{\circ} \mathrm{F}$, and different pressures for the Standing and the new models for solubility and bubble point pressure, in GOR $=300(\mathrm{scf} / \mathrm{stb})$ the Standing model predicts different values of $\mathrm{Pb}$ at different temperatures, and the trends of calculated oil FVF is changed at these bubble pressures. However, the calculated value of $\mathrm{Pb}$ by Equation (2) for the same temperature is more than 3000 psi. Therefore, the new model and the Standing model result in different values. In addition, as stated in Equations (8)-(10), solubility and bubble pressure influence oil FVF as well. Figure 6 shows that the calculated oil density for the two models significantly depends on bubble pressure. The values for $\mathrm{Pb}$ in the two models are similar to Figure 6. Below the bubble pressure, when pressure increases, oil density decreases, and above the bubble pressure, oil density increases with increasing pressure, and the minimum value for oil density occurs at the bubble point. This is remarkable considering that the mixture density is a substantial parameter in pressure calculations. Evaluation of mixture density, no-slip and slip holdup, and in-situ velocities strongly depend on the volumetric flow rate of phases. Figure 7 compares the calculated oil flow rate in the case of using the new models and the Standing model. The results are significantly different. Furthermore, the maximum value for oil flow rate occurs at bubble point just in the case of using the Standing equation. Consequently, using Standing solubility and bubble pressure for calculating oil flow rate led to the overestimation of the oil flow rate. Figure 8 shows that the void fraction is lower in the case of using the new models compared to the case of using the Standing model. Figure 9 illustrates the effect of using the new equations versus the Standing correlations for bubble point and solubility in viscosity calculations. It could be seen that the viscosity obtained from the Standing is lower than the one obtained from the new relations. Since the viscosity has a direct relation 
with pressure drop and friction factor in flowing fluid at the pipe and well, finding the precise amount of this parameter is important in dual gradient drilling technology.

From equations in Section 3.7 and the preceding equations, it can be seen that the Rs and $\mathrm{Pb}$ models affect viscosity, velocity, no-slip density ( $\rho n)$, and liquid holdup in Reynolds number and consequently, the friction factor. Therefore, using proper solubility and bubble pressure models, such as the new models for Nitrogen and white oil mixture in dual gradient drilling, plays a crucial role in finding the accurate amount of Reynolds number and friction factor. As discussed in previous sections, all mentioned PVT parameters such as formation volume factor, flow rate, density, viscosity, velocity, holdup, and friction factor strongly depend on the solubility and bubble pressure. Consequently, the total pressure (same as bottom hole pressure in the bottom of the well) strongly relies on bubble pressure and solubility of gas and liquid mixture.

After calculating PVT parameters, another important issue in dual gradient drilling technology, same as in underbalanced drilling, is optimizing the flow rate of the injected gas. During the application of both these technologies, a gas (such as Nitrogen) is injected into a liquid (such as gasoline or oil). Therefore, evaluating the gas flow rate versus bottom hole pressure is of crucial importance. Gas injection implies the idea that how much gas should be injected into the liquid to decrease the bottom hole pressure to the desired amount. Furthermore, the solubility and bubble pressure models affect choosing the optimum gas injection rate. It was found that in the case of using new relations of bubble point and solubility instead of Standing bubble point and solubility model, the bottom hole pressures decrease especially at higher liquid (oil and water mixture) flow rates and also at lower gas flow rates. The discrepancy between pressures for the new models and the Standing model in the hydrostatic-dominated area is higher at the lower gas flow rate. One reason for this difference is that in lower gas flow rates, the solubility and bubble pressure is more important in comparison to higher gas flow rates. In addition, the difference between pressures for the new models and the Standing model in the hydrostatic-dominated area is larger at higher liquid flow rates. This difference is because, in high liquid rates, there is more gas that can be dissolved in the oil-based drilling fluids and the solubility and bubble pressure model become more influential in comparison to the lower liquid flow rate at low gas flow rates. In a higher gas flow rate (frictional-dominated area), the resultant pressure has no big differences for low and high liquid flow rates.

After all, it should be mentioned that the Standing model has already proved very effective for reservoir engineering tasks, but to the authors' best knowledge, it has not been particularly optimized or altered considering the specific properties of the drilling fluid. The standing model is based on natural gases such as methane, ethane etc., but has not been particularly improved for drilling where Nitrogen and oil, and in particular "Nitrogen and white mineral oil (\#5)" as adopted in this study, are used together.

\section{Limitations and Future Extensions}

The most noticeable limitation of the present study and the developed new models is that the adopted methods are rather conventional and require traditional experimental procedures. The requirement for the precise setting of the experimental apparatus as well as precise control of the experimental procedure is also laborious and time-consuming. Moreover, these new models are also developed in the laboratory-based on a limited number of experiments and for a particular type of mixture, i.e., "Nitrogen and white mineral oil (\#5)". Therefore, the generalization of these basic models requires further investigation and improvements. Moreover, we only implemented the Drift Flux model for calculating pressure while other models such as Lattice Boltzmann [45], mechanical methods, or computational fluid dynamic (CFD) could also be used. There have been many studies on various methods for obtaining the bubble point pressure in the published literature, but there has not been an organized study on "comparing the performance of various models in obtaining the bubble point pressure in dual gradient gas drilling", and therefore, it would be suggested as a topic for future research. The aforementioned 
existing studies have covered such aspects as reviewing the correlations of the bubble point pressure and oil formation volume factor [46], novel empirical correlations for estimation of bubble point pressure [47], prediction of bubble point pressure, and bubble point oil formation volume factor in the absence of PVT analysis [48], comparing bubble point pressure of irreverent, crude oils [49], application of artificial intelligence techniques [50], and adopting the technique of Boosting ensembles [51]. However, the reason for selecting the Drift Flux model in the present study was that it is one of the widely-used models in two-phase drilling projects and enables obtaining a high calculation speed and a high precision. Finally, for calculating the distribution parameter $\left(c_{0}\right)$ and the drift velocity $\left(v_{D}\right)$ as in Equations (18) and (19), methods other than the one used in the present study are also applicable. Nevertheless, future extensions to the current study would include investigating the application of the synthetic oil-based mud instead of the white mineral oil used in the present research. Besides, there are still many unknown aspects of applying the new interdisciplinary investigation techniques in assessing the gas solubility, bubble point pressure, bottom hole pressure or temperature, gas injection rate, etc., throughout dual gradient drilling or other deepwater drilling tasks. These techniques include fractal geometry theory [52-55], digital rock technology [56-58], one-dimensional [59-62] and two-dimensional nuclear magnetic resonance [63,64], numerical methods [65-67], artificial intelligence [68-72] especially the deep learning technique [73-75], which could be used individually or in a joint manner during well planning, design, engineering, operations, and technology application, etc. This wide range of topics is suggested as the potential areas of future research. Figure 12 summarizes the general advantages, limitations, and also future extensions of the present study in a concise form.

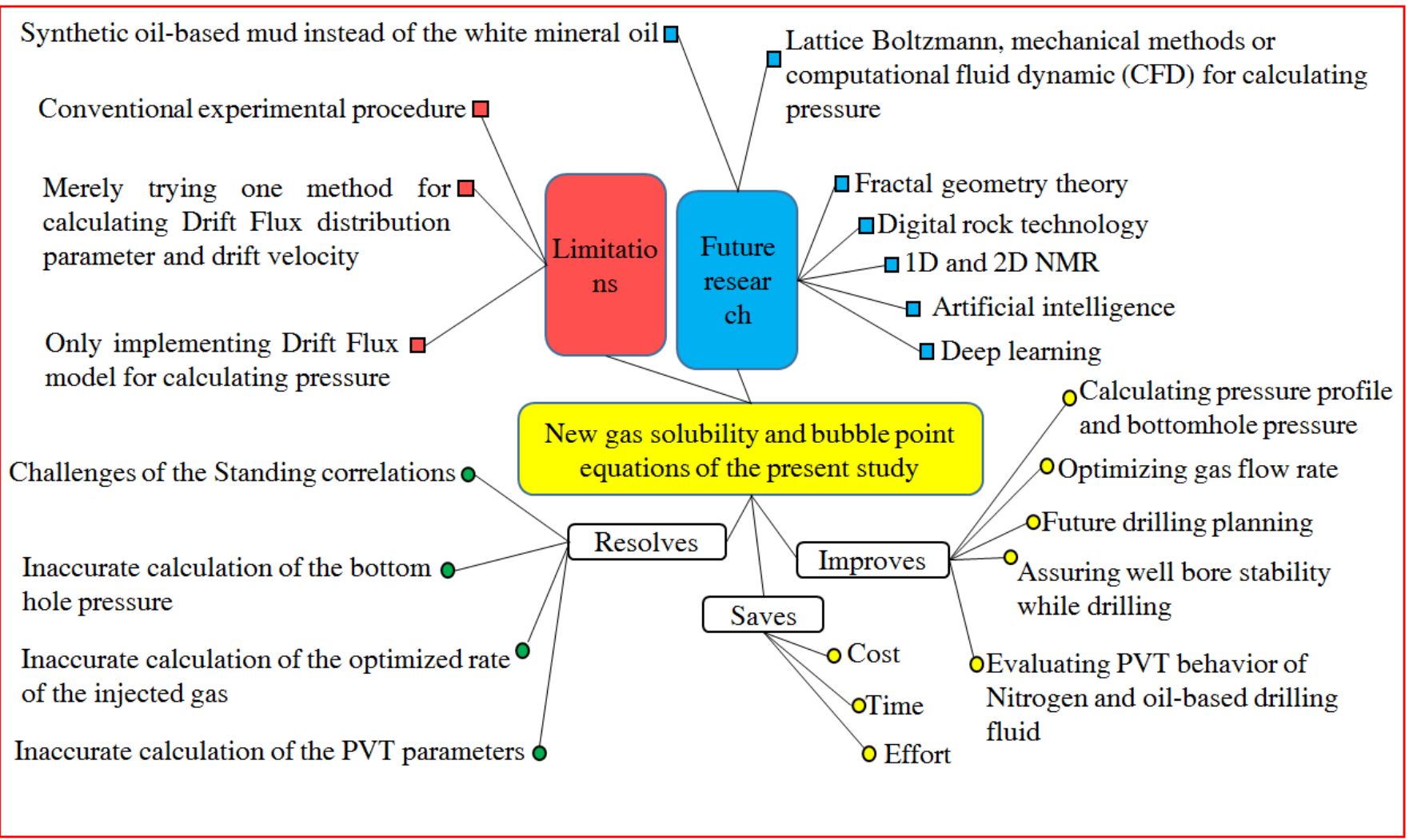

Figure 12. A detailed look into the limitations as well as possible future extensions to the present study. 


\section{Conclusions}

In the current study, the effect of using two new models, namely the solubility equation and the bubble point equation, on PVT parameters was compared with the case of using Standing correlations for solubility and bubble pressure. Accordingly, the bottom hole pressure was calculated for the two new models and the Standing model. Finally, the influence of different models on the optimum amount of injected gas in liquid was examined, and then, different results were discussed. After all, it could be concluded that the gas-lift dual gradient drilling is an applicable drilling method in deepwater drilling. Inside the deep wells, the temperature and pressure are variable; therefore, their effects on PVT properties of drilling fluid should be considered during gas-lift DGD. In addition, the effect of solubility and bubble point should be investigated carefully while OBM is applied as the drilling fluid. Based on the obtained results, it can be concluded that when using the Standing solubility and bubble pressure models instead of the new models, the oil FVF and the oil flow rate are overestimated; and at higher pressures, the oil density is overestimated as well. Besides, the void fraction and oil viscosity are underestimated when Standing correlations are used. Consequently, when using Nitrogen and white oil (or similar oilbased muds) in gas-lift dual gradient drilling, applying the Standing solubility and bubble point models (or the other Black oil models) leads to overestimation or underestimation of some important PVT parameters, which is not recommended; but the new models are reliable for these kinds of calculations. Moreover, for optimizing injected gas rate design, at the low liquid (oil and water mixture) flow rates, the results of bottom hole pressures are not sensitive to solubility and bubble point model. Nevertheless, at the high liquid (oil and water mixture) rates, the bottom hole pressure values are sensitive to solubility and bubble point models, especially for low injected gas rates; because bottom hole pressure was overestimated whilst using the Standing correlations for bubble point pressure and solubility instead of the new equations.

Author Contributions: Conceptualization: N.G. and S.N. Methodology: B.G. and S.N. Software and formal analysis: N.G. and S.N. Investigation: N.G. and B.G. Validation: B.G. Writing-Original Draft: N.G. and S.N. Writing-Review \& Editing: B.G. All authors have read and agreed to the published version of the manuscript.

Funding: This research was funded by the "Taishan Scholar Talent Team Support Plan for Advantaged and Unique Discipline Areas" of China, the "Taishan Scholars Young Expert Program" of China, the National Natural Science Foundation of China (Grant No: 520095077), and the Natural Science Foundation of Shandong Province (Grant No: ZR2019ZD14). These supports are gratefully acknowledged.

Data Availability Statement: The developed codes could be found at https:/ / data.mendeley.com/ datasets/rzf53yzvm3/1 (doi:10.17632/rzf53yzvm3.1).

Conflicts of Interest: The authors declare no conflict of interest.

\section{Nomenclature}

$\begin{array}{lll}R_{s} & \text { Solution gas-oil ratio } & \mathrm{scf} / \mathrm{STB} \\ P & \text { Pressure } & \mathrm{Psi} \\ T & \text { Temperature } & { }^{\circ} \mathrm{F} \\ P_{b} & \text { Bubble point pressure } & \mathrm{Psi} \\ T_{s c} & \text { Standard temperature } & { }^{\circ} \mathrm{R} \\ z & \text { Distance } & \mathrm{ft} \\ \rho_{m} & \text { Mixture density } & \mathrm{lbm} / \mathrm{ft}^{3} \\ f_{m} & \text { Mixture friction factor } & - \\ u_{m} & \text { Mixture velocity } & \mathrm{ft} / \mathrm{s} \\ D_{h} & \text { Hydraulic diameter } & \mathrm{ft} \\ g & \text { Gravitational acceleration constant } & \mathrm{ft} / \mathrm{s}^{2} \\ \rho_{n} & \text { No-slip density } & \mathrm{lbm} / \mathrm{ft}^{3}\end{array}$


$H_{L}$

$\mathrm{C}_{\mathrm{O}}$

$\gamma_{0}$

$\gamma_{g}$

$\rho_{L}$

$\rho_{g}$

$\rho_{o}$

$\rho_{w}$

$f_{0}$

$f_{w}$

GOR

$\gamma_{o(s c)}$

$\gamma_{g(s c)}$

$\gamma_{w(s c)}$

$c_{0}$

$v_{D}$

$D_{i}$

$D_{o}$

$\alpha_{g}$

$V_{s g}$

$V_{s l}$

$V_{m}$

$\mu_{o}$

$\mu_{w}$

$\mu_{l}$

$\mu$

$\mu_{s}$

$\mu_{n}$

$H_{g}$

$\lambda$

$\lambda_{l}$

$\lambda_{g}$

$q_{g(s c)}$

$q_{o(s c)}$

$q_{w(s c)}$

$q_{w}$

$q_{g}$

$q_{l}$

qo

A
Friction factor

Formation volume factor

Gas compressibility factor

Gas formation volume factor

Water formation volume factor

Oil formation volume factor

Oil formation volume factor at bubble point pressure

Liquid-holdup

Oil compressibility

Specific gravity of the oil

Specific gravity of the solution gas

Liquid density

Gas density

Oil density

Water density

Oil volume fraction

Water volume fraction

Gas-oil ratio

Specific gravity of oil at standard condition

Specific gravity of the solution gas at standard condition

Specific gravity of water at standard condition

Distribution parameter

Drift velocity

Well internal diameter

Drill-string outer diameter

Void fraction

Gas superficial velocity

Liquid superficial velocity

Mixture velocity

Oil viscosity

Water viscosity

Liquid viscosity

Viscosity

Slip viscosity

No-slip viscosity

Gas holdup

No-slip holdup

No-slip liquid holdup

No-slip gas holdup

Gas flow rate at standard condition

Oil flow rate at standard condition

Water flow rate at standard condition

In situ water flow rate

In situ gas flow rate

In situ liquid flow rate

In situ oil flow rate

Cross-sectional area of the flow $\mathrm{ft}^{3} / \mathrm{scf} \& \mathrm{bbl} / \mathrm{STB}$

$\mathrm{ft}^{3} / \mathrm{scf}$

$\mathrm{bbl} / \mathrm{STB}$

$\mathrm{bbl} / \mathrm{STB}$

$\mathrm{bbl} / \mathrm{STB}$

-

$\mathrm{psi}^{-1}$

$-$

$-$

$\mathrm{lbm} / \mathrm{ft}^{3}$

$\mathrm{lbm} / \mathrm{ft}^{3}$

$\mathrm{lbm} / \mathrm{ft}^{3}$

$\mathrm{lbm} / \mathrm{ft}^{3}$

$-$

$-$

scf/STB

$-$

$-$

$-$

$\mathrm{ft} / \mathrm{s}$

in

in

$-$

$\mathrm{ft} / \mathrm{s}$

$\mathrm{ft} / \mathrm{s}$

$\mathrm{ft} / \mathrm{s}$

$\mathrm{cp}$

cp

$\mathrm{cp}$

$\mathrm{cp}$

cp

$\mathrm{cp}$

-

$-$

$-$

$\mathrm{scf} / \mathrm{s}$

$\mathrm{scf} / \mathrm{s}$

$\mathrm{scf} / \mathrm{s}$

$\mathrm{ft}^{3} / \mathrm{s}$

$\mathrm{ft}^{3} / \mathrm{s}$

$\mathrm{ft}^{3} / \mathrm{s}$

$-$

$\mathrm{ft}^{2}$

\section{Appendix A. Further Experimental Details}

Nitrogen and white mineral oil (\#5) were supplied from the market. The oil was tested on a gas-chromatograph/flame-ionization detector (GC/FID) to analyze the components and on a pycnometer for obtaining density. Table A1 represents the composition of the white mineral oil (\#5). 
Table A1. Composition of white mineral oil (\#5).

\begin{tabular}{ll}
\hline Component & Weight $\%$ \\
\hline$<\mathrm{nC13}$ & 00.51 \\
$\mathrm{nC} 13$ & 00.81 \\
vIso paraffin $\mathrm{nC} 13-\mathrm{nC} 14$ & 20.75 \\
nC14 & 13.60 \\
Iso paraffin nC14-nC15 & 32.72 \\
nC15 & 15.30 \\
Iso paraffin nC15-nC16 & 14.82 \\
nC16 < & 01.05 \\
\hline
\end{tabular}

At first, the test was conducted at $68^{\circ} \mathrm{F}$. Since it was difficult to identify the single and two-phase regions in the $P-V$ diagram especially, at high temperatures, the visual observation was used to analyze the bubble pressure, which offered the feasibility of observing the bubble stability. After the mixture became saturated and clear bubbles were observed, the experiment for the desired temperature was finished. For the same volume of liquid and gas, the temperature of the mixture was set to $122^{\circ} \mathrm{F}$, and another CCE test was performed. When experiments were conducted at 68,122 , and $176^{\circ} \mathrm{F}$ for the desired gas and liquid volume, the next designed gas volume was introduced to the free-gas oil sample, and the test was repeated at 68,122 , and $176^{\circ} \mathrm{F}$ again. Table A2 includes the designed liquid and gas volumes at different temperatures. This table represents 18 designed tests that were selected for 6 different molar fractions of Nitrogen at temperatures of 68,122 , and $176^{\circ} \mathrm{F}$. It is worth mentioning that some tests were repeated to increase the accuracy of the models. When the solubility of Nitrogen in white mineral oil at temperatures of 68 , 122 , and $176^{\circ} \mathrm{F}$ was plotted, it turned out to increase at various saturation pressures as the temperature increased. Table A2 represents the final results of selected experiments. This table was used in MATLAB for finding solubility and bubble pressure of white mineral oil and Nitrogen at different pressures and temperatures (the new models). The behavior of Nitrogen in the n-paraffin (Decane) [18] and the solubility at various temperatures in the experiments were considerably consistent, and the major trends were the same as the results of Tong et al. [18]. It must be mentioned that for the constant molar fraction of Nitrogen, at higher temperatures, saturation pressure (bubble pressure) decreased, i.e., solubility was increased. The measured solubility in the experiment was quite compatible with data from Rommetveit and Vefring [16] for the Nitrogen solubility in OBDF at $68^{\circ} \mathrm{F}$, and the trends were similar. The slight difference could be due to the different types of oil-based drilling fluid.

Table A2. Details of experiments and the obtained data.

\begin{tabular}{|c|c|c|c|c|c|c|c|}
\hline \multicolumn{4}{|c|}{ The Designed Liquid and Gas Volume } & \multicolumn{4}{|c|}{ Final Results of PVT Experiment } \\
\hline Test & $\begin{array}{l}\text { Gas Volume }(\mathrm{mL}) \text { at } \\
\text { Standard Condition }\end{array}$ & $\begin{array}{c}\text { Gas Mole Fraction } \\
\text { in Mixture }\end{array}$ & $\begin{array}{c}\text { Temperature } \\
\left({ }^{\circ} \mathrm{F}\right)\end{array}$ & $\begin{array}{c}\text { Nitrogen } \\
\text { Mole Fraction }\end{array}$ & $R s$ (scf/stb) & $T\left({ }^{\circ} \mathbf{F}\right)$ & $\begin{array}{c}P_{b} \\
\text { (psi) }\end{array}$ \\
\hline 1 & 540 & 0.024 & 68 & 0.024 & 14.80 & 68 & 406.11 \\
\hline 2 & 975 & 0.043 & 68 & 0.043 & 26.73 & 68 & 725.19 \\
\hline 3 & 1900 & 0.081 & 68 & 0.081 & 52.09 & 68 & 1406.87 \\
\hline 4 & 2530 & 0.105 & 68 & 0.105 & 69.36 & 68 & 1812.97 \\
\hline 5 & 2805 & 0.116 & 68 & 0.116 & 76.90 & 68 & 2005.87 \\
\hline 6 & 3415 & 0.137 & 68 & 0.137 & 93.62 & 68 & 2436.63 \\
\hline 7 & 540 & 0.024 & 122 & 0.024 & 14.80 & 122 & 394.50 \\
\hline 8 & 975 & 0.043 & 122 & 0.043 & 26.73 & 122 & 671.52 \\
\hline 9 & 1900 & 0.081 & 122 & 0.081 & 52.09 & 122 & 1359.00 \\
\hline 10 & 2530 & 0.105 & 122 & 0.105 & 69.36 & 122 & 1740.45 \\
\hline 11 & 2805 & 0.116 & 122 & 0.116 & 76.90 & 122 & 1929.00 \\
\hline 12 & 3415 & 0.137 & 122 & 0.137 & 93.62 & 122 & 2291.60 \\
\hline 13 & 540 & 0.024 & 176 & 0.024 & 14.80 & 176 & 364.04 \\
\hline
\end{tabular}


Table A2. Cont.

\begin{tabular}{|c|c|c|c|c|c|c|c|}
\hline \multicolumn{4}{|c|}{ The Designed Liquid and Gas Volume } & \multicolumn{4}{|c|}{ Final Results of PVT Experiment } \\
\hline Test & $\begin{array}{l}\text { Gas Volume }(\mathrm{mL}) \text { at } \\
\text { Standard Condition }\end{array}$ & $\begin{array}{l}\text { Gas Mole Fraction } \\
\text { in Mixture }\end{array}$ & $\begin{array}{c}\text { Temperature } \\
\left({ }^{\circ} \mathrm{F}\right)\end{array}$ & $\begin{array}{c}\text { Nitrogen } \\
\text { Mole Fraction }\end{array}$ & $R s$ (scf/stb) & $T\left({ }^{\circ} \mathbf{F}\right)$ & $\begin{array}{c}P_{b} \\
\text { (psi) }\end{array}$ \\
\hline 14 & 975 & 0.043 & 176 & 0.043 & 26.73 & 176 & 646.87 \\
\hline 15 & 1900 & 0.081 & 176 & 0.081 & 52.09 & 176 & 1292.29 \\
\hline 16 & 2530 & 0.105 & 176 & 0.105 & 69.36 & 176 & 1667.93 \\
\hline 17 & 2805 & 0.116 & 176 & 0.116 & 76.90 & 176 & 1841.98 \\
\hline 18 & 3415 & 0.137 & 176 & 0.137 & 93.62 & 176 & 2190.07 \\
\hline
\end{tabular}

\section{References}

1. Bakhshi, E.; Golsanami, N.; Chen, L. Numerical modeling and lattice method for characterizing hydraulic fracture propagation: A review of the numerical, experimental, and field studies. Arch. Comput. Methods Eng. 2020, 28, 3329-3360. [CrossRef]

2. Golsanami, N.; Bakhshi, E.; Yan, W.; Dong, H.; Barzgar, E.; Zhang, G.; Mahbaz, S. Relationships between the geomechanical parameters and Archie's coefficients of fractured carbonate reservoirs: A new insight. Energy Sour. Part A Recover. Util. Environ. Eff. 2020, 1-25. [CrossRef]

3. Hammer, W.L.; Walker, J.A. Evaluation of aerated drilling fluids used at the Nevada test site. In Proceedings of the SPE Annual Technical Conference and Exhibition, Las Vegas, NV, USA, 23-26 September 1979. [CrossRef]

4. Rizo, T.M.; Cuenca, A.P. Aerated fluid drilling observations in geothermal operation in Luzon, Philippines. In Proceedings of the Society of Petroleum Engineers—Southeast Asia Show, SEA, Singapore, 21-24 February 1984; pp. 1481-1496. [CrossRef]

5. Guo, B.; Hareland, G.; Rajtar, J. Computer simulation predicts unfavorable mud rate and optimum air injection rate for aerated mud drilling. SPE Drill. Complet. 1996, 11, 61-66. [CrossRef]

6. Lopes, C.A.; Bourgoyne, A.T. The dual density riser solution. In Proceedings of the SPE/IADC Drilling Conference, Amsterdam, The Netherlands, 4-6 March 1997. [CrossRef]

7. Nakagawa, E.Y.; Santos, H.; Cunha, J.C.; Shayegi, S. Planning of deepwater drilling operations with aerated fluids. In Proceedings of the SPE Asia Pacific Oil and Gas Conference and Exhibition, Jakarta, Indonesia, 20-22 April 1999. [CrossRef]

8. Nakagawa, E.Y.; Silva, V.; Boas, M.B.V.; Silva, P.R.C.; Shayegi, S. Comparison of aerated fluids/foam drilling hydraulics simulators against field data. In Proceedings of the Society of Petroleum Engineers-SPE Asia Pacific Oil and Gas Conference and Exhibition, Jakarta, Indonesia, 20-22 April 1999. [CrossRef]

9. Herrmann, R.P.; Shaughnessy, J.M. Two methods for achieving a dual gradient in deepwater. In Proceedings of the Drilling Conference, Amsterdam, The Netherlands, 27 February-1 March 2001; pp. 412-429. [CrossRef]

10. Perez-Tellez, C.; Smith, J.R.; Edwards, J.K. A new comprehensive, mechanistic model for underbalanced drilling improves wellbore pressure predictions. In Proceedings of the SPE International Petroleum Conference and Exhibition in Mexico, Villahermosa, Mexico, 1-12 February 2002; pp. 1-13. [CrossRef]

11. Stanislawek, M.; Smith, J.R. Analysis of alternative well-control methods for dual-density deepwater drilling. In Proceedings of the IADC/SPE Drilling Conference, Miami, FL, USA, 21-23 February 2006. [CrossRef]

12. Smith, J.R.; Stanislawek, M.; Shelton, J. Literature Review Summary for Comparative Analysis of Dual Density Drilling Systems to Reduce Deepwater Drilling Costs; Research Partnership to Secure Energy for America: Houston, TX, USA, 2003.

13. Lopes, C.A. Feasibility Study on the Reduction of Hydrostatic Pressure in a Deep-Water Riser Using a Gas-Lift Method. Ph.D. Thesis, Louisiana State University and Agricultural and Mechanical College, Baton Rouge, LA, USA, 1997.

14. Dilchert, G.; Kuss, E. The experimental determination of gas solubility in mineral-oils and the viscosity-pressure behavior of the gas/oil solution up to 1 Kbar. In Proceedings of the 9025-MS SPE, London, UK, October 1980.

15. Rommetveit, R.; Olsen, T.L. Gas kick experiments in oil-based drilling muds in a full-scale, inclined research well. In Proceedings of the SPE Annual Technical Conference and Exhibition, San Antonio, TX, USA, 8-11 October 1989. [CrossRef]

16. Rommetveit, R.; Vefring, E.H. Comparison of results from an advanced gas kick simulator with surface and downhole data from full scale gas kick experiments in an inclined well. In Proceedings of the SPE Annual Technical Conference and Exhibition, Dallas, TX, USA, 6-9 October 1991. [CrossRef]

17. Bassani, R.; Piccigallo, B. Hydrostatic Lubrication: Theory and Practice; Elsevier: Amsterdam, The Netherlands, 1992.

18. Tong, J.; Gao, W.; Robinson, R.L.; Gasem, K.A.M. Solubilities of nitrogen in heavy normal paraffins from 323 to 423 K at pressures to $18.0 \mathrm{MPa}$. J. Chem. Eng. Data 1999, 44, 784-787. [CrossRef]

19. O'Bryan, P.L. The Experimental and Theoretical Study of Methane Solubility in an Oil-Base Drilling Fluid. Louisiana State University: Baton Rouge, LA, USA, 1985.

20. Thomas, D.C.; Lea, J.F.J.; Turek, E. Gas Solubility in oil-based drilling fluids: Effects on kick detection. J. Pet. Technol. 1984, 36, 959-968. [CrossRef]

21. Standing, M.B. A Pressure-Volume-Temperature Correlation for Mixtures of California Oils and Gases; American Petroleum Institute: Washington, DC, USA, 1947; pp. 275-287.

22. Glaso, O. Generalized pressure-volume-temperature correlations. J. Pet. Technol. 1980, 32, 785-795. [CrossRef] 
23. Negahban, S.; Ruihe, W.; Baojiang, S. Experimental measurement and modeling of the solubility and bubble pressure of nitrogen in white mineral oil. Pet. Sci. Technol. 2016, 34, 1818-1825. [CrossRef]

24. Golsanami, N. Evaluating the Effect of New Gas Solubility and Bubble Point Models on PVT Parameters and Optimizing Injected Gas Rate in Gas-Lift Dual Gradient Drilling, Mendeley Data, V1, 2021. Available online: https:/ / data.mendeley.com/datasets/ rzf53yzvm3/1 (accessed on 23 October 2021). [CrossRef]

25. Li, X.; Gao, D.; Zhou, Y.; Zhang, H. A model for extended-reach limit analysis in offshore horizontal drilling based on formation fracture pressure. J. Pet. Sci. Eng. 2016, 146, 400-408. [CrossRef]

26. Li, J.; Zhang, H.; Li, X.; Ding, S.; Tao, Q. Dual-gradient drilling of deepwater in south china sea: What is the well's maximum measured depth and how to improve it. In Proceedings of the SPE/IADC Managed Pressure Drilling and Underbalanced Operations Conference and Exhibition, New Orleans, LA, USA, 17-18 April 2018.

27. Shen, P.; Li, G.; Liu, J.; Li, X.; Zhang, J. Gas permeability and production potential of marine hydrate deposits in South China sea Energies 2019, 12, 4117. [CrossRef]

28. Kumar, D. Managed Pressure Drilling: Experimental and Modeling Based Investigation. Master's Thesis, Pandit Deendayal Petroleum University, Gandhinagar, India, 2010.

29. Geo Drilling Fluids Inc. Technical Services Newsletter, Managed Pressure Drilling; Geo Drilling Fluids Inc.: Bakersfield, CA, USA, 2004; Volume 8, p. 3.

30. Guo, B.; Liu, G. Applied Drilling Circulation Systems: Hydraulics, Calculations, and Models; Gulf Professional Publishing: Houston, TX, USA, 2011; ISBN 978-0123819574.

31. Elieff, B.A.M. Top Hole Drilling with Dual Gradient Technology to Control Shallow Hazards. Master's Thesis, Texas A\&M University, College Station, TX, USA, 2006.

32. Hannegan, D.; Todd, R.J.; Pritchard, D.M.; Jonasson, B. MPD—Uniquely applicable to methane hydrate drilling. In Proceedings of the SPE/IADC Underbalanced Technology Conference and Exhibition, Houston, TX, USA, 11-12 October 2004.

33. Fossil, B.; Sangesland, S. Managed pressure drilling for subsea applications; well control challenges in deep waters. In Proceedings of the SPE/IADC Underbalanced Technology Conference and Exhibition, Houston, TX, USA, 11-12 October 2004.

34. Brill, J.P. Multiphase flow in wells. J. Pet. Technol. 1987, 39, 15-21. [CrossRef]

35. Dranchuk, P.; Abou-Kassem, H. Calculation of Z Factors for Natural Gases Using Equations of State. J. Can. Pet. Technol. 1975, 14, 34-36. [CrossRef]

36. McCain, W.D., Jr. The Properties of Petroleum Fluids. Available online: https://www.researchgate.net/publication/261652188_ The_Properties_of_Petroleum_Fluids (accessed on 23 October 2021).

37. Elsharkawy, A.M.; Alikhan, A.A. Models for predicting the viscosity of middle east crude oils. Fuel 1999, 78, 891-903. [CrossRef]

38. James, P.; Brill, H.D.B.; James, P.; Brill, H. Dale Beggs-Two-Phase Flow in Pipes-Tulsa University Press. Available online: https:/ / www.scribd.com/document/481871050/James-P-Brill-H-Dale-Beggs-Two-Phase-Flow-in-Pipes-Tulsa-UniversityPress-1991-compressed (accessed on 23 October 2021).

39. Zuber, N.; Findlay, J.A. Average volumetric concentration in two-phase flow systems. J. Heat Transf. 1965, 87, 453-468. [CrossRef]

40. Hasan, A.R.; Kabir, C.S. Predicting multiphase flow behavior in a deviated well. SPE Prod. Eng. 1988, 3, 474-482. [CrossRef]

41. Lee, A.L.; Gonzalez, M.H.; Eakin, B.E. The viscosity of natural gases. J. Pet. Technol. 1966, 18, 997-1000. [CrossRef]

42. Beggs, H.D.; Robinson, J.R. Estimating the viscosity of crude oil systems. J. Pet. Technol. 1975, 27, 1140-1141. [CrossRef]

43. Vasquez, M.; Beggs, H.D. Correlations for fluid physical property prediction. J. Pet. Technol. 1980, 32, 968-970. [CrossRef]

44. Beggs, H.D.; Brill, J.R. Study of two-phase flow in inclined pipes. J. Pet. Technol. 1973, 25, 607-617. [CrossRef]

45. Golsanami, N.; Jayasuriya, M.N.; Yan, W.; Fernando, S.G.; Liu, X.; Cui, L.; Zhang, X.; Yasin, Q.; Dong, H.; Dong, X. Characterizing clay textures and their impact on the reservoir using deep learning and lattice-boltzmann simulation applied to SEM images. Energy 2022, 240, 122599. [CrossRef]

46. Al-Shammasi, A.A. A review of bubblepoint pressure and oil formation volume factor correlations. SPE Reserv. Eval. Eng. 2001, 4, 146-160. [CrossRef]

47. Khamehchi, E.; Rashidi, F.; Rasouli, H.; Ebrahimian, A. Novel empirical correlations for estimation of bubble point pressure, saturated viscosity and gas solubility of crude oils. Pet. Sci. 2009, 6, 86-90. [CrossRef]

48. Elmabrouk, S.; Zekri, A.; Shirif, E. Prediction of bubblepoint pressure and bubblepoint oil formation volume factor in the absence of pvt analysis. In Proceedings of the SPE Latin American and Caribbean Petroleum Engineering Conference Proceedings, Lima, Peru, 1-3 December 2010; Volume 1, pp. 217-225.

49. Ahmadi, M.A.; Pournik, M.; Shadizadeh, S.R. Toward connectionist model for predicting bubble point pressure of crude oils: Application of artificial intelligence. Petroleum 2015, 1, 307-317. [CrossRef]

50. Baarimah, S.O.; Gawish, A.A.; BinMerdhah, A.B. Artificial intelligence techniques for predicting the reservoir fluid properties of crude oil systems. Int. Res. J. Eng. Technol. 2015, 2, 373-382.

51. Alatefi, S.; Almeshal, A.M. A new model for estimation of bubble point pressure using a bayesian optimized least square gradient boosting ensemble. Energies 2021, 14, 2653. [CrossRef]

52. Han, B.; Lu, G.; Cao, H.; Zhang, L. Fractal features of the microstructure of the drilling fluid used into the hydrate-bearing sediments under the shearing action. Environ. Earth Sci. 2017, 76, 1-13. [CrossRef]

53. Golsanami, N.; Fernando, S.G.; Jayasuriya, M.N.; Yan, W.; Dong, H.; Cui, L.; Dong, X.; Barzgar, E. Fractal properties of various clay minerals obtained from SEM images. Geofluids 2021, 2021, 1-18. [CrossRef] 
54. Dong, H.; Sun, J.; Golsanami, N.; Cui, L.; Jiang, L.; Yan, G.; Yan, W.; Li, Y. A method to construct high-precision complex pore digital rock. J. Geophys. Eng. 2018, 15, 2695-2703. [CrossRef]

55. Dong, H.; Sun, J.; Cui, L.; Golsanami, N.; Yan, W.; Huaimin, D.; Jianmeng, S.; Likai, C.; Naser, G.; Weichao, Y. Characteristics of the pore structure of natural gas hydrate reservoir in the Qilian mountain permafrost, Northwest China. J. Appl. Geophys. 2019, 164, 153-159. [CrossRef]

56. Sun, J.; Dong, H.; Arif, M.; Yu, L.; Zhang, Y.; Golsanami, N.; Yan, W. Influence of pore structural properties on gas hydrate saturation and permeability: A coupled pore-scale modelling and X-ray computed tomography method. J. Nat. Gas Sci. Eng. 2021, 88, 103805. [CrossRef]

57. Dong, H.; Cui, L.; Yu, L.; Song, L.; Sun, J.; Golsanami, N.; Liu, X. New hybrid method for gas-hydrate digital rock reconstruction and its accuracy evaluation. J. Energy Eng. 2021, 147, 4021050. [CrossRef]

58. Liu, X.; Dong, H.; Yan, W.; Arif, M.; Zhang, Y.; Golsanami, N. Influence of gas hydrate saturation and pore habits on gas relative permeability in gas hydrate-bearing sediments: Theory, experiment and case study. J. Nat. Gas Sci. Eng. 2021, 95, 104171. [CrossRef]

59. Liu, X.; Dong, X.; Golsanami, N.; Liu, B.; Shen, L.W.; Shi, Y.; Guo, Z.; Cui, L.; Sun, Y.; Du, Y.; et al. NMR characterization of fluid mobility in tight sand: Analysis on the pore capillaries with the nine-grid model. J. Nat. Gas Sci. Eng. 2021, 94, 104069. [CrossRef]

60. Golsanami, N.; Zhang, X.; Yan, W.; Yu, L.; Dong, H.; Dong, X.; Cui, L.; Jayasuriya, M.N.; Fernando, S.G.; Barzgar, E. NMR-based study of the pore types' contribution to the elastic response of the reservoir rock. Energies 2021, 14, 1513. [CrossRef]

61. Dong, X.; Shen, L.W.; Golsanami, N.; Liu, X.; Sun, Y.; Wang, F.; Shi, Y.; Sun, J. How N2 injection improves the hydrocarbon recovery of $\mathrm{CO}_{2} \mathrm{HnP}$ : An NMR study on the fluid displacement mechanisms. Fuel 2020, 278, 118286. [CrossRef]

62. Golsanami, N.; Sun, J.; Liu, Y.; Yan, W.; Lianjun, C.; Jiang, L.; Dong, H.; Zong, C.; Wang, H. Distinguishing fractures from matrix pores based on the practical application of rock physics inversion and NMR data: A case study from an unconventional coal reservoir in China. J. Nat. Gas Sci. Eng. 2019, 65, 145-167. [CrossRef]

63. Horkowitz, J.; Crary, S.; Ganesan, K.; Heidler, R.; Luong, B.; Morley, J.; Petricola, M.; Prusiecki, C.; Poitzsch, M.; Scheibal, J.R.; et al Applications of a new magnetic resonance logging-while-drilling tool in a Gulf of Mexico deepwater development project. In Proceedings of the SPWLA 43rd Annual Logging Symposium, Oiso, Japan, 2-5 June 2002.

64. Yan, W.; Sun, F.; Sun, J.; Golsanami, N. Distribution model of fluid components and quantitative calculation of movable oil in inter-salt shale using 2D NMR. Energies 2021, 14, 2447. [CrossRef]

65. Gao, X.; Zheng, H.; Zhang, Y.; Golsanami, N. Tax policy, environmental concern and level of emission reduction. Sustainability 2019, 11, 1047. [CrossRef]

66. Zhang, X.; Jiang, Y.; Chen, L.; Wang, X.; Golsanami, N.; Zhou, L. Anti-plane seismic performance of a shallow-buried tunnel with imperfect interface in anisotropic half-space. Tunn. Undergr. Space Technol. 2021, 112, 103906. [CrossRef]

67. Dong, X.; Shen, L.; Zhao, J.; Liu, X.; Sun, Y.; Golsanami, N.; Wang, F.; Bi, H.; Zitha, P. A novel method to evaluate cleaning quality of oil in shale using pyrolysis pyrogram. Energy Sci. Eng. 2020, 8, 1693-1704. [CrossRef]

68. Ahmed, A.; Elkatatny, S.; Ali, A.; Abughaban, M.; Abdulraheem, A. Application of artificial intelligence techniques in predicting the lost circulation zones using drilling sensors. J. Sensors 2020, 2020, 1-18. [CrossRef]

69. Agwu, O.E.; Akpabio, J.U.; Alabi, S.B.; Dosunmu, A. Artificial intelligence techniques and their applications in drilling fluid engineering: A review. J. Pet. Sci. Eng. 2018, 167, 300-315. [CrossRef]

70. Golsanami, N.; Kadkhodaie-Ilkhchi, A.; Erfani, A. Synthesis of capillary pressure curves from post-stack seismic data with the use of intelligent estimators: A case study from the Iranian part of the South Pars gas field, Persian Gulf Basin. J. Appl. Geophys. 2015, 112, 215-225. [CrossRef]

71. Golsanami, N.; Sun, J. Developing a new technique for estimating NMR T1 and T2 relaxations. In Proceedings of the 79th EAGE Conference and Exhibition, Paris, France, 12-15 June 2017.

72. Qiang, Z.; Yasin, Q.; Golsanami, N.; Du, Q. Prediction of reservoir quality from log-core and seismic inversion analysis with an artificial neural network: A case study from the Sawan Gas Field, Pakistan. Energies 2020, 13, 486. [CrossRef]

73. Jiang, L.; Zhao, Y.; Golsanami, N.; Chen, L.; Yan, W. A novel type of neural networks for feature engineering of geological data: Case studies of coal and gas hydrate-bearing sediments. Geosci. Front. 2020, 11, 1511-1531. [CrossRef]

74. Zhao, S.; Shadabfar, M.; Zhang, D.; Chen, J.; Huang, H. Deep learning-based classification and instance segmentation of leakage-area and scaling images of shield tunnel linings. Struct. Control Health Monit. 2021, 28, e2732. [CrossRef]

75. Yasin, Q.; Ding, Y.; Baklouti, S.; Boateng, C.D.; Du, Q.; Golsanami, N. An integrated fracture parameter prediction and characterization method in deeply-buried carbonate reservoirs based on deep neural network. J. Pet. Sci. Eng. 2022, $208,109346$. [CrossRef] 